\title{
LOS INVENTARIOS POST MORTEM DE LA VALENCIA MEDIEVAL. UNA FUENTE PARA EL ESTUDIO DEL CONSUMO DOMÉSTICO Y LOS NIVELES DE VIDA*
}

\author{
POSTMORTEM INVENTORIES IN MEDIEVAL VALENCIA. \\ A SOURCE FOR THE STUDY OF HOUSEHOLD CONSUMPTION \\ AND LIVING STANDARDS
}

\author{
LUIS ALMENAR FERNÁNDEZ \\ Universitat de València \\ http://orcid.org/0000-0003-1417-8523
}

\begin{abstract}
Resumen: Los inventarios post mortem de la Valencia bajomedieval apenas han sido sometidos a algunas cuestiones básicas sobre su naturaleza ¿Qué los distinguía de otras listas de bienes y cuál era su fundamentación legal? ¿Por qué se realizaban? ¿Qué bienes recogían y cuáles omitían? ¿Cuántos inventarios se conservan en la actualidad? ¿Qué sectores de la sociedad medieval los solicitaban? Las respuestas que proporciona este artículo hacen evidente la potencialidad de un uso seriado y cuantitativo del inventario valenciano para el estudio del consumo doméstico, una vía de análisis que permitiría medir con precisión cambios en los niveles de vida de la sociedad bajomedieval a un nivel muy difícil de lograr en otras regiones de Europa.
\end{abstract}

Palabras clave: inventarios; consumo; niveles de vida; Valencia; Baja Edad Media.

\begin{abstract}
Basic questions about the nature of postmortem inventories in late medieval Valencia have rarely been asked. What distinguished them from other lists of goods and what was their legal basis? Why were inventories made? Which goods were listed and which ones omitted? How many inventories are preserved today? Which sectors of medieval society requested them? The answers that this paper provides clearly show the potential of a serial and quantitative usage of the Valencian inventory for the study of household consumption, an analysis that would enable us to measure far more accurately the changes in living standards in late medieval society to a degree that is difficult to achieve in other regions of Europe.
\end{abstract}

Keywords: inventories; consumption; standards of living; Valencia; later Middle Ages.

\footnotetext{
* Este trabajo forma parte del proyecto de investigación "Crecimiento económico y desigualdad social en la Europa mediterránea, siglos XIII-XV", financiado por el Ministerio de Educación, Cultura y Deporte del Gobierno de España (HAR2014-58730-P), dirigido desde la Universitat de València por Antoni Furió. El autor de texto es beneficiario de una ayuda de Formación del Profesorado Universitario (FPU) del mismo ministerio. El autor desea agradecer los comentarios, sugerencias y ayuda prestada durante la elaboración de este trabajo a Antoni Furió, Juan Vicente García Marsilla, Enric Guinot, Mateu Rodrigo, Ferran Garcia-Oliver, Antonio José Mira, Pau Viciano, Josep Torró y Luis Pablo Martínez.
} 


\section{SUMARIO}

1. Introducción.-2. Un mundo de inventarios. Las listas de bienes de la Europa preindustrial.- 3. Entre la ley y la praxis. Las causas de la redacción.- 4. Inventarios e interior doméstico.- 5. ¿Una sociedad del inventario?.- 6. Conclusión.- 7. Bibliografía citada.

\section{INTRODUCCIÓN ${ }^{1}$}

El estudio del consumo y la comercialización ocupa un lugar central en la investigación reciente sobre la economía del reino de Valencia durante los últimos siglos de la Edad Media. Cada vez es mejor conocido cómo los mercados implicaban progresivamente a más sectores sociales y fomentaban la distribución de todo tipo de productos a escala local y regional, un proceso estructurado desde las principales villas del reino que también alcanzaba al medio rural. Todo ello no sólo está permitiendo comprender cómo la demanda y el consumo podían ser una fuerza motriz de la economía, sino que sugiere la existencia de una sociedad valenciana que adquirió más bienes en el transcurso de los siglos XIV y XV, en el marco de una Corona de Aragón que seguía procesos similares ${ }^{2}$. Sin embargo, la idea de un aumento de la globalidad de lo consumido - del consumo agregado-, no puede ser sino la manifestación total, macroeconómica, de transformaciones a una escala mucho más "micro" que están aún por abordar y diseccionar a fondo. Se trata de los cambios en el seno de la casa y la familia, de la unidad doméstica como célula básica de adquisición de bienes que hubo de ser la base del crecimiento del consumo agregado. Porque en efecto, los productos que circulaban y nutrían los mercados acababan de una manera u otra en casas, y eran utilizados por las personas que las habitaban en su día a día. Y si para la perspectiva del consumo como una realidad total las fuentes pueden ser muy diversas, para estudiar el consumo doméstico existe una fuente cuya centralidad es máxima: los inventarios post mortem.

Estas listas de bienes no son una novedad entre los historiadores del reino de Valencia, que las conocen y están acostumbrados a ver y utilizar

${ }^{1}$ Abreviaturas utilizadas: AMV = Arxiu Municipal de València; APPV = Arxiu de Protocols del Patriarca de València; ARV = Arxiu del Regne de València; Inv. = inventario; Alm. = almoneda.

${ }^{2}$ Para el caso de la Corona de Aragón véase Guinot 2014; Furió 2010; Garcia-Oliver 2006; los dos capítulos sobre el mercado en Salrach, Giralt 2004; Sesma, Laliena 2009. Para una óptica peninsular López 2011, y para una panorámica europea Blondé, Stabel, Boone 2006. Para el caso inglés, cuya historiografía es la base de muchas de estas temáticas, Kowaleski 2006; Dyer 1998, 2005 y Britnell 1996. 
desde por lo menos los inicios del siglo XX. Por aquel entonces los estudiosos de los inventarios eran filólogos y archiveros, personas en contacto directo con la documentación notarial que reproducían con "curiosidad" -una palabra muy repetida en sus obras- el estilo de vida y la lengua del pueblo valenciano cuando éste aún tenía su propio reino ${ }^{3}$. El empleo de inventarios para el estudio de la economía valenciana es algo mucho más reciente, que recibió un impulso fundamental con la renovación historiográfica que protagonizó la llamada "escuela valenciana" en los años 1980-1990, un uso que se ha vuelto frecuente al tratar el propio tema del consumo y su vinculación con el más complejo debate sobre las transformaciones en los niveles de vida ${ }^{4}$. Estos estudios han aportado una base indispensable para el conocimiento de la cultura material bajomedieval, si bien la manera de abordar los inventarios es a menudo auxiliar, plasmando el contenido de cómo mucho una decena de inventarios en una descripción transversal de los enseres recogidos. No se han emprendido aún estudios cuantitativos que procesen los inventarios de manera seriada, abarcando cientos o miles de estos documentos, lo que hace muy difícil poder explorar con precisión cambios en las pautas de consumo doméstico de grupos sociales o tipos de bienes concretos. Y esto es del todo posible porque el inventario post mortem valenciano no era una anomalía documental, sino una fuente que estuvo bien presente en la Europa preindustrial, con la que los historiadores de otros países y épocas se han enfrentado precisamente de esta forma en repetidas ocasiones.

Existen, de hecho, al menos dos tradiciones de uso de inventarios post mortem en la historia económica. La primera de ellas es la que estudia la relación entre "los hombres y las cosas", como proponía Fernand Braudel, y explora las características y las prácticas de uso de los objetos en su contexto social cotidiano. Esto lleva a menudo a una impresión descriptiva de la realidad material, que se inserta como refuerzo de argumentaciones mayores sobre dinámicas de cambio social y económico 5 . Pero existe otra tradición, a la cual los medievalistas han recurrido menos, que se desarrolló en el seno de la historiografía británica a raíz de la decisiva obra The birth of a consumer

\footnotetext{
${ }^{3}$ Ejemplos de esta aproximación son Julià 1921; Ferrer 1926. Véase Vercher 2005, guía bibliográfica con referencias a este tipo de trabajos a escala local y Europea.

${ }^{4}$ Los inventarios aparecen referidos en las monografías de estudios locales o regionales que ya son parte de los "clásicos" de la historiografía valenciana renovada: Furió 1982 pp. 141-144; Viciano 1989, pp. 127-139; Vercher 1992; Garcia-Oliver 2003, pp. 28-37; Ferragud 2003, pp. 215-218. Además, cada vez es más común encontrar trabajos o apartados dedicados a aspectos de la cultura material a través de inventarios post mortem: García-Marsilla 1993, pp. 145-183; Navarro 2005, García-Marsilla 2001, 2011.

${ }^{5}$ La monumental obra Braudel 1984 fue sin duda un impulso para esta vía, que ha estimulado algunos de los grandes trabajos por los que se conoce a los propios inventarios, como Mazzi, Raveggi 1983 y Roche 2000.
} 
society, una sociedad de consumo que habría surgido en la Inglaterra del Setecientos. La dinámica de la moda y la distinción, el hecho de que las clases medias imitaran las pautas de consumo de las élites y de que éstas a su vez trataran de distinguirse adquiriendo nuevos bienes, habría sido el motor de una "revolución de consumo", el shock en el lado de la demanda que motivaría la reacción de los productores y el surgimiento de la revolución industrial ${ }^{6}$. Esta revolución de consumo era, no obstante, una revolución sin inventarios, que se basaba en el estudio de empresas comerciales, sistemas de venta y publicidad, y que se apoyaba en conceptos más culturales que económicos ${ }^{7}$. La idea llevó a una oleada de historiadores a trabajar cientos de inventarios para comprobar si, desde el punto de vista de la unidad doméstica, la sociedad inglesa había accedido a más y mejores bienes durante el largo siglo XVIII ${ }^{8}$. Fueron estos trabajos los que iniciaron una tradición de análisis de inventarios profundamente cuantitativa y seriada, desarrollando una serie de métodos que continúan perfeccionándose en la actualidad en la historiografía de época moderna. Los trabajos más recientes de Mark Overton estudian decenas de miles de inventarios desde perspectivas diversas, desde la cantidad, la calidad, la gama o la frecuencia de aparición de los bienes hasta el análisis lingüístico de palabras que expresan lujo o novedad ${ }^{9}$. Muchas de estas técnicas se han ido aplicando en la historiografía moderna de Castilla y Cataluña gracias a la influencia de los trabajos de Bartolomé Yun y Jaume Torras, que han sido desarrollados más recientemente por Belén Moreno y Fernando Carlos Ramos $^{10}$.

Tales aproximaciones exigían una comprensión profunda de la naturaleza del inventario, no sólo de qué circunstancias legales provocaban su redacción, sino también de sus límites de representatividad material -qué bienes recogen- y social -qué grupos sociales encargaban inventarios-, así como de los problemas teóricos de aproximar el consumo desde una fuente que aporta una imagen fija de los bienes y no su ritmo de adquisición ${ }^{11}$. No es exagerado hablar de la existencia de una auténtica historiografía del inventario, de sus posibilidades para el estudio del consumo doméstico, en la

\footnotetext{
${ }^{6}$ McKendrick, Brewer, Plumb 1982, pp. 1-13.

${ }^{7}$ Vries 1993, pp. 87 y 89.

${ }^{8}$ Shammas 1990; Weatherill 1996; Brewer, Porter 1993.

${ }^{9}$ Overton, et al. 2004. Para otras aproximaciones de este tipo véanse los trabajos citados en De Vries 2008, pp. 123-126.

${ }^{10}$ Torras, Yun 1999; Moreno 2007; Ramos 2011.

${ }^{11}$ Bolòs, Sànchez-Boira 2014, vol. I, pp. 39-81; Ramos 2011; Sobrado 2003. El interés por los límites de los inventarios también ha motivado dos congresos y sus correspondientes monografías: Baulant, Schuurman, Servais 1988; Van Der Woude, Schuurman 1980.
} 
cual los ejemplos medievales permanecen mayoritariamente en la sombra ${ }^{12}$. Este trabajo pretende situar los ejemplares valencianos de la Baja Edad Media dentro de ese ámbito de discusión. ¿Qué distingue en realidad a los inventarios post mortem de otras listas de bienes? ¿Qué circunstancias legales provocaban su redacción? ¿Qué miembros de la sociedad los ordenaban? ¿Son los bienes que recogen estos elencos todo lo que se hallaba en el interior de la casa? Y la pregunta más importante, ¿hasta qué punto nos aproximan o alejan los inventarios valencianos del consumo doméstico? Responder a estas preguntas, que tanto han preocupado a los historiadores del consumo en otros países y épocas, es el objetivo de las próximas páginas.

\section{UN MUNDO DE INVENTARIOS. LAS LISTAS DE BIENES DE LA EUROPA PREINDUSTRIAL}

Los inventarios post mortem valencianos no son un unicum, sino un instrumento jurídico que podía encontrarse en otras regiones de la Europa preindustrial. Lo que en el ámbito hispánico se denomina inventarios o inventaris post mortem ha recibido muchos otros nombres entre los historiadores europeos, como inventaires aprés décès, inventari di beni ereditali, probate inventories, Nachlaßinventaren o staten van goed. A pesar de que estas listas de bienes se enmarcaran en sociedades y sistemas jurídicos particulares, diferentes en el espacio y en el tiempo, todas ellas recogían enseres bajo una circunstancia común, la de ser aquellos que constituían una herencia, transmitida a causa de una defunción, y realizada a petición de los herederos o de sus tutores, si estos eran menores de edad.

La mayoría de estos documentos no se conservan antes de 1500, lo que explica la escasa reflexión en el panorama historiográfico europeo sobre la naturaleza de esta tipología de inventarios durante la época medieval. De hecho, los dos grandes congresos que se han dedicado íntegramente a los inventarios apenas dedicaron atención a los ejemplares de la Edad Media. Dejando a un lado excepciones, se argumentaba, todos parecen haber comenzado a existir en algún punto entre el siglo XVI y XVIII ${ }^{13}$. Esta valoración tradicional sobre la escasa "medievalidad" de la fuente hace tiempo que ha dejado de sostenerse. Hoy sabemos que este tipo de inventarios existía ya desde el siglo XIII en el sur de Francia, los diversos países de la Corona de Aragón y seguramente también en Italia. Los ejemplares de Castilla e Inglaterra no se remontan más

\footnotetext{
${ }^{12}$ Para la Corona de Aragón en la Baja Edad Media contamos fundamental y casi únicamente con las aportaciones en Bolòs, Sànchez-Boira 2014; Benito 2008; Garcia-Oliver 2006.

${ }^{13}$ Van Der Woude, Schuurman 1980, p. 4.
} 
allá de finales del siglo XV, desde luego no volviéndose comunes hasta el siglo $\mathrm{XVI}$, cuando comienzan a aparecer en los archivos holandeses y alemanes. En todo caso, no es hasta los siglos XVII y XVIII cuando se documentan ya ampliamente por todo el norte y sur de la geografía europea, encontrándose en lugares tan distantes como Suecia o Suiza, pero también más allá de Europa, en los territorios de la América colonial o incluso de la Creta otomana ${ }^{14}$.

Los orígenes conocidos de la fuente están así en la Europa mediterránea del siglo XIII, la Europa del notariado y, en definitiva, la Europa de la recuperación del derecho romano. Es de hecho en el Corpus Iuris Civilis de Justiniano donde se encuentra el fundamento legal del inventario que acostumbramos a denominar post mortem, entre las leyes referentes a la transmisión de la herencia. Ésta podía ser aceptada o rechazada íntegramente por los herederos, y tomar una decisión así requería tener un buen conocimiento de causa de las posesiones que la componían, especialmente ante la obligación del heredero de pagar las temidas deudas, que también eran parte de lo heredado. Ante ello, la herencia podía aceptarse "a beneficio de inventario", afrontando la deuda únicamente con los propios bienes que se iban a heredar, no con aquellos que eran posesión personal del heredero, y esto hacía necesaria la realización de un inventario exhaustivo de dichos bienes ${ }^{15}$. En el caso de que los herederos fueran menores de edad estos necesitaban un tutor legal, y éste también debía realizar un inventario al principio de su administración de los bienes de los menores ${ }^{16}$.

Estas dos circunstancias provocaban la redacción de los inventarios mencionados anteriormente a escala europea, particularidades que no sólo definen al inventario post mortem como una realidad legal concreta, sino que también lo distingue de otras listas de bienes. Porque en efecto, existía una pluralidad de documentos que recogían las posesiones de las personas que vivieron en la Europa preindustrial. Algunas de las más conocidas son aquellas que resultaban de otros momentos de la transmisión patrimonial, como las donaciones inter vivos o propter nunptias, las cartas dotales, los contratos de comunidad de bienes o las particiones, documentos que solían recoger diversos enseres domésticos y que, en definitiva, no dejaban de ser inventarios. Lo mismo ocurría con otras listas de bienes que, al contrario que los inventarios post mortem, eran ordenados por personas ajenas al dueño

\footnotetext{
${ }^{14}$ Para referencias a los inventarios del siglo XIII véase Isnard, d'Agnel 1914 para Francia, y Batlle 1988 para Cataluña. En Valencia y Mallorca se conservan en los protocolos notariales de las últimas décadas de ese siglo. Para el resto de países la cronología se fundamenta en las menciones en Torras, Yun 1999; Lencina 1998; Baulant, Schuurman, Servais 1988; Van Der Woude, Schuurman 1980.

${ }^{15}$ Krueger 1877 , pp. $562-565$.

${ }^{16}$ El digesto de Justiniano. Tomo II: Libros 20-36, p. 225.
} 
de los enseres y a sus intereses. Los inventarios de bienes embargados que se encuentran dispersos entre los registros judiciales son un ejemplo de ello, pero también existían otros inventarios menos conocidos realizados en el interior del mundo señorial, que debían de formar parte del repertorio de derechos jurisdiccionales de la nobleza feudal europea. Estos pueden localizarse en diferentes puntos del continente como resultado de causas parecidas, como en Borgoña y en diversos condados ingleses durante los siglos bajomedievales. Aquí, el derecho de expropiar los bienes de los campesinos que morían intestados, cometían acciones ilegales graves (felonía) o huían de sus dominios conllevaba la redacción de un inventario de los bienes incautados ${ }^{17}$.

Tanto los inventarios judiciales como los señoriales eran un acto externo a los intereses del dueño de las posesiones o de sus familiares y allegados, por lo que existe una alta posibilidad de que los conocidos del difunto ocultaran bienes antes de la expropiación. Además, la impresión que dan estos documentos suele ser de parcialidad. En el caso de los inventarios ordenados por instituciones judiciales se expropiarían los bienes necesarios para cubrir únicamente la deuda contraída. Por su parte, los inventarios señoriales raramente aspiraban a hacer un elenco de todos los bienes, sino sólo de los más valiosos, lo que derivaba en una omisión sistemática de los enseres de bajo valor. De hecho, en algunos lugares de Inglaterra estos inventarios se llamaban significativamente principalia, cuando lo listado eran los objetos más estimables del expropiado, o terciars, cuando se trataba de una tercera parte ${ }^{18}$.

Pero el inventario post mortem no era una imposición, sino un derecho del que lo solicitaba y que esperaba beneficiarse de él. Podría pensarse que su escasez en ciertos lugares y períodos es fruto de una mala conservación de los registros notariales, pero sería un error creer que este documento se realizaba únicamente dentro de la práctica del notario en tanto que en su ejercicio de la fides publica. Diferentes autoridades y poderes daban respaldo legal a la misma tipología de inventario que producían los notarios en el sur de Europa. En Dijon, eran las autoridades urbanas en representación del maire las que expedían inventarios a los habitantes de la ciudad ${ }^{19}$. En Inglaterra, donde el notariado tenía una presencia muy marginal como intermediario legal, era la Iglesia la que se encargaba de toda la documentación relacionada con la transmisión de la herencia, lo que incluía testamentos, codicilos e inventarios.

${ }^{17}$ Para el caso francés véase Piponnier 1980, pp. 128-136; 1987. Para el caso inglés Briggs 2008, pp. 2-5; Dyer 1998, pp. 169-175.

${ }^{18}$ Briggs 2008, pp. 2-5; Dyer 1998, pp. 169-175. Véase también Piponnier 1987, p. 236.

${ }_{19}$ Piponnier 1980, 1987. Estos inventarios se publicarán pronto por Guilhem Ferrand, a quien agradezco sus comentarios sobre la naturaleza y particularidades de los inventarios de Dijon. 
Era en las cortes parroquiales en las que se dividía todo el país donde se expedían estos documentos, alcanzando incluso las zonas más remotas ${ }^{20}$.

\section{ENTRE LA LEY Y LA PRAXIS. LAS CAUSAS DE LA REDACCIÓN}

Aunque el origen romanista del documento explique unas causas de redacción relativamente comunes a escala europea, cada inventario se insertaba en un marco legal y social, lo que implicaba motivos particulares para su escritura. En el reino de Valencia, como ocurría en otros lugares de la Corona de Aragón, ordenar inventarios era obligatorio únicamente en ciertas circunstancias. Los Furs de Valencia, al igual que el derecho catalán, contemplaban la redacción de inventarios por las dos razones relacionadas con la transmisión post mortem de la herencia que ya aparecían mencionadas en el Corpus de Justiniano. Los herederos tenían lo dret del inventari ben fet, el de pagar las deudas del difunto hasta donde lo permitiera el valor de los bienes heredados, para lo cual era necesario inventariarlos. En este caso el inventario era una potestad del heredero y era, por tanto, completamente prescindible ${ }^{21}$.

No obstante, si los herederos eran menores de edad o pubills necesitaban un tutor-que cuidaría de ellos- y un curador -que administraría sus bienes-. Estos cargos solían coincidir en la misma persona, normalmente un pariente cercano o un vecino. En cualquier caso, tutores y curadores debían realizar un seguimiento detallado de su gestión del patrimonio de los herederos bajo su cuidado, que se entregaba al justícia de la localidad en la que residieran en un período de tres años tras el fin de la tutela ${ }^{22}$. Todo este proceso sólo podía tener lugar tras la redacción de un listado inicial de los bienes de los menores, por lo que en este caso la realización del inventario sí que era una necesidad, sin el cual la tutela no podía comenzar ${ }^{23}$. Esto conllevaba

\footnotetext{
${ }^{20}$ Este sistema es el llamado probate system, de ahí el nombre históricamente dado a estos tres documentos, probate records, y a los propios inventarios, probate inventories.

${ }^{21}$ Colón, Garcia 1970-2007, vol. V, pp. 236-237. El heredero tenía derecho a encargar este inventario en los tres meses siguientes al conocimiento de la herencia ofrecida (Marzal 1998, pp. 48-50). En Cataluña, por su parte, el inventario debía empezarse antes de que se cumpliera un mes de la muerte del difunto, y acabarse antes del fin del segundo mes (Bolòs, SànchezBoira 2014, vol. I, p. 42).

${ }^{22}$ Colón, Garcia 1970-2007, vol. II, pp. 223-224; vol. III, p. 13. Se han conservado muy pocos cuadernos de administración de tutelas. Véanse los ejemplares transcritos en Guinot, Furió 1980; Aparici, Navarro 1996-1997.

${ }^{23}$ Colón, Garcia 1970-2007, vol. V, p. 78. La obligatoriedad de realizar inventario como paso previo a la administración de unos bienes ocurría también en el caso de las viudas en Cataluña. Desde la constitución Hac Nostra (1351), aquellas mujeres que desearan acceder al usufructo de los bienes del difunto marido para su propia manutención durante el año de luto (any de plor) estaban obligadas a ordenar previamente un inventario. Véase Benito 2008, nota 11.
} 
que algunos inventarios post mortem fueran encargados por las autoridades municipales en su faceta de veladoras del porvenir de huérfanos y niños en la miseria. Si los pubills quedaban huérfanos sin que hubiera tutores designados por un testamento, el consell de la localidad podía designar un tutor o curador de oficio, y éste también debía realizar un inventario ${ }^{24}$.

Había en teoría otros motivos que podían requerir la redacción de inventarios, aunque son difícilmente rastreables en la documentación. Aquel heredero "gravat de substitució", es decir, el sustituto del heredero principal, también debía ordenarlo si el primero fallecía antes del reparto de los bienes ${ }^{25}$. Por otra parte, la muerte de individuos intestados y sin parientes dentro del reino podía provocar la existencia de un grueso de bienes sin dueño, que si no eran reclamados en un plazo de dos años, se inventariaban, se vendían en pública subasta y el dinero se daba para obras pías ${ }^{26}$.

Ahora bien, contemplar las razones de la redacción del inventario sólo desde el punto de vista de la ley foral nos reduciría a ver la utilidad del documento únicamente para las instituciones. Al igual que los testamentos u otros documentos relacionados con el derecho sucesorio, los inventarios cumplían una función pública central al aportar seguridad jurídica a algo tan esencial para la reproducción de la riqueza de los habitantes del reino como era la transmisión hereditaria. Pero más allá de las circunstancias que la ley pudiera contemplar, en la base, estaba la lógica de las necesidades de familias concretas. Los inventarios cumplían primero una función privada, doméstica y familiar, que era la de ser un seguro legal al que los miembros de la sociedad medieval podían recurrir. Maria Serena Mazzi ya expresó esta idea fundamental poniendo la razón del inventario, antes que en la ley, en la costumbre que genera la propia desconfianza de las personas ${ }^{27}$. De hecho, su cláusula introductoria más popular no deja de recordar su fin principal, tanto en latín -cum ob doli maculam evitandam-como en catalán - esquivar tota frau e engan $-^{28}$.

En la práctica, por tanto, cualquier situación litigiosa podía estimular el encargo de inventarios, toda una casuística de inseguridades que abarcaba desde una inesperada muerte sin testamento, el desacuerdo con las últimas voluntades del difunto o la existencia de bienes cuya propiedad se hallaba en disputa. Esto último debió de ser lo que llevó a la madre de Gonçal Molina

${ }^{24}$ Ésta es la llamada "tutela dativa". Colón, Garcia 1970-2007, vol. V, p. 76.

${ }^{25}$ Colón, Garcia 1970-2007, vol. V, pp. 220-221.

${ }^{26}$ Ibidem, pp. 197-198.

${ }^{27}$ Mazzi 1980, p. 207.

${ }^{28}$ Estas cláusulas, con pequeñas variaciones, se repiten en los inventarios de todas las áreas catalanoparlantes. Véanse para Cataluña los inventarios reproducidos en Bolòs, Sànchez-Boira 2014 y Benito 2008, y los de Barceló 1994 para Mallorca. 
en 1396 a ordenar un inventario de su escasa ropa y, sobre todo, sus lxx florins, los quals se pledegen ab n'Esteve d'Algària, sin contar los otros cuatrocientos florines que tenía Pere Llopis ${ }^{29}$. Incluso algunas personas en el límite de la vida y la muerte ya debían de percibir la intranquilidad en su entorno más próximo por cuáles eran sus posesiones, llevándoles a ordenar inventarios de sus bienes antes de fallecer, como la viuda Francesca, que lo hacía per sa mal(al)tia, per ço que aprés obte de aquella puxa ésser haüda memòria ${ }^{30}$.

Resulta muy difícil cuantificar este tipo de situaciones, que sólo pueden sospecharse de comentarios breves como los anteriores. Por sí mismos, la mayoría de inventarios sólo mencionan la causa de su redacción cuando ésta era alguna de las contempladas en la ley foral, y aún así esto no ocurre en todos los documentos. La figura 1 revela este hecho a partir de una muestra de inventarios de la segunda mitad del siglo XIV. Más de la mitad no eran explícitos sobre el motivo de su redacción. Sólo un $41 \%$ lo era, pero dado que en términos absolutos esa proporción representa 72 ejemplares, ésta en sí misma es una cantidad significativa de la que se pueden extraer algunas ideas. Las causas por las que se hicieron estos inventarios abarcaban de manera abrumadora dos cuestiones, el acceso a tutelas y la aceptación de la herencia a beneficio de inventario. De esos 72 inventarios, prácticamente dos tercios se realizaron por tutores, y el tercio restante por herederos accediendo a la herencia con la condición del listado notarial. Resulta interesante observar la existencia de una opción intermedia, la aceptación de la tutela a beneficio de inventario, que la realizaron una decena de los tutores.

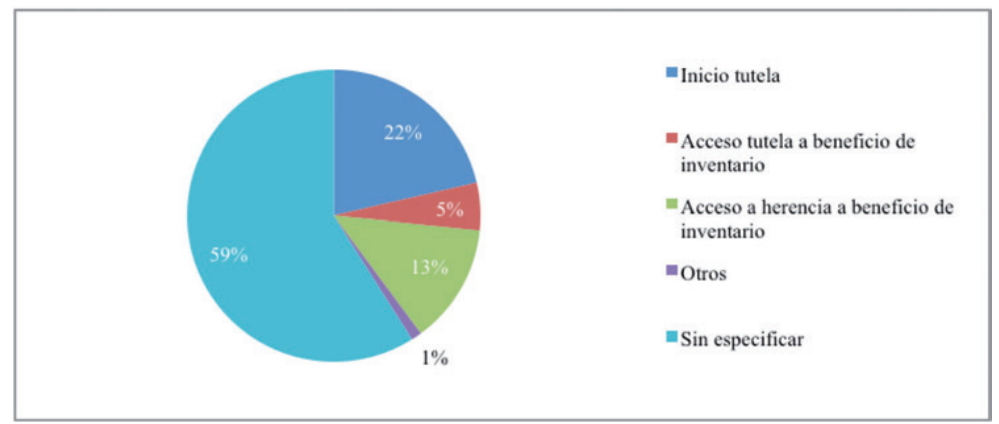

Fig. 1. Razón de redacción de un corpus de inventarios post mortem valencianos $(1348-1400)^{31}$.

\footnotetext{
${ }^{29}$ APPV, Antoni Pasqual, 23.233, 5 de febrero de 1395.

${ }^{30}$ APPV, Jaume Vinader, $9.531,8$ de enero de 1438.

${ }^{31}$ La gráfica se basa en una muestra de 173 inventarios, procedentes de todos los protocolos notariales del APPV y el AMV entre 1348 y 1400 . La cantidad total en este período y archi-
} 
De la muestra anterior, 2 ejemplares (el 1\% llamado "otros") corresponden a los bienes del interior de dos iglesias, que pasarían a ser gestionados por un nuevo cargo eclesiástico, quienes obviamente sólo poseían esos bienes en tanto que administradores ${ }^{32}$. De una forma u otra, el inventario dejaba por escrito la pretensión de acceder a unos bienes tras la muerte de aquel que los había poseído, y esta funcionalidad llevaba a que se hicieran inventarios que iban más allá de la lógica estrictamente sucesoria. Ejemplos similares muestran cómo bajo las fórmulas notariales habituales se recogían los enseres de sedes de cofradías, parroquias y hospitales, que no pasaban de dueño a dueño, sino de un usufructuario a otro. Así ocurrió en 1420, cuando un procurador de la ciudad de Valencia y Jaume Cabanes, el nuevo draçaner de las atarazanas, hacían una lista de las galeras del puerto tal y como las había dejado el draçaner saliente ${ }^{33}$. Lo mismo pasaba con hospitales y cofradías, en los que el paso de un espitaler o un clavari a uno nuevo podía hacer deseable ver el estado en que quedaban los bienes al tomar el cargo ${ }^{34}$. En la práctica, en definitiva, cualquiera que comenzara a administrar los bienes de otro podía ver el inventario como algo deseable ${ }^{35}$.

\section{INVENTARIOS E INTERIOR DOMÉSTICO}

¿Qué bienes recogen los inventarios? Estudiar el consumo a través de ellos hace obligado valorar hasta dónde llegaba la exhaustividad del elenco notarial. Desde luego, los ejemplares valencianos suelen ser tan minuciosos que resulta difícil pensar que puedan estar ignorando algún bien, pues abarcan desde bienes inmuebles y animales hasta alimentos como queso o tocino. Entre ambos extremos emerge todo un universo de enseres acompañados de las más variadas referencias a su material, forma, calidad e incluso color. Este grado de detalle es probablemente lo que ha dotado a la fuente de una variedad de calificativos visuales que se repiten en la bibliografía, valorándolos como "espejos", "instantáneas" o "fotografías" de la realidad material que rodeaba al difunto, que habrían sido el resultado de la inspección ocular de los notarios.

vos es de 200 ejemplares, pero 27 no eran utilizables para los fines de esta gráfica.

${ }^{32}$ La de Sant Miquel y Santa Maria, ambas de la villa de Morvedre, en 1348. AMV, Domingo Joan, 1-1, 17 de julio y 31 de diciembre de 1348 respectivamente.

${ }^{33}$ AMV, Jaume Desplà, n-19, 6 de marzo de 1414.

${ }^{34}$ García-Marsilla 2011; Gallent 2010-2011.

${ }^{35}$ Las cláusulas notariales en ocasiones lo mencionan de forma explícita: "hi que bona aliena incipiunt administrare inventarium seu repertorium de bonis minorum vel defunctorum tenetur facere." 
Pero en realidad, el inventario es un documento mucho más selectivo de lo que parece por su propia funcionalidad legal: hacer constar los bienes de una persona. Y esto no era lo mismo que anotar todos los bienes que había en la casa en la que vivía el fallecido, aunque los hubiera utilizado en vida o estuvieran presentes cuando se redactó el documento. Al fin y al cabo, eran los bienes del difunto a aquellos a los que podían aspirar legítimamente quienes habían ordenado el inventario, que normalmente eran la viuda, que pretendía recuperar su dote, y los hijos, buscando obtener su herencia. De hecho, en contra de la imagen del notario anotando los bienes en solitario, estas personas aparecen constantemente en el momento de la redacción del listado, y dado que el notario no podía saber cuáles eran los bienes del difunto, eran ellos los que debían de decírselo ${ }^{36}$. Además, esto tenía lugar en medio de una discusión entre ambas "partes" -como se las denomina en diversos documentos- que ha quedado fosilizada en los inventarios de casos especialmente conflictivos, donde los familiares aparecen recurrentemente diciéndole al notario qué anotar. Así ocurrió en 1443 en el inventario de la viuda Ylària, cuyos albaceas no dejaban de discutir sobre el paradero de la plata de la difunta, lo que llevo al notario Jaume Vinader a escribir las acusaciones mutuas que se lanzaban entre ellos ${ }^{37}$. Los inventarios que por voluntad del difunto incluyen estimaciones monetarias también han dejado rastro de estos debates, lo que era comprensible dado que entonces el problema ya no era sólo saber qué era de quién, sino cuánto valía cada cosa. Entonces se recurría a personas expertas en representación de cada parte, para que dieran un valor de mutuo acuerdo. Esto es lo que hicieron los albaceas y la viuda del labrador Gil Joan, que pidieron los servicios de dos pellers, uno por parte de la viuda y otro por parte de los albaceas, y de un corredor, que aconsejaría a ambos ${ }^{38}$.

Esta identificación de los bienes por parte de los familiares del difunto era la base de la elaboración del inventario, y explica la habilidad de distinguir los enseres de un individuo de entre otros. Esto queda patente

${ }^{36}$ Los familiares, como dicen los propios inventarios, eran aquellos que "sciunt vel scire debent facultates deffuncti”. Su presencia la exigía además la ley del reino al menos en el caso de las tutelas (Marzal 1998, pp. 50-51).

37 "Ítem, dix e requerí lo dit en Bernat Serra en lo dit nom mi, dit Jaume Vinader, receptor del present inventari, que metés e continuàs en lo dit present inventari dos copes d'argent daurades. Îtem, quatre culeretes d'argent. Ítem, una correga d'argent. Ítem, quatrecens reals d'argent, les quals copes, culeretes, corega e diners lo dit frare Johan de continent, après òbit de la dita mare sua, havia pres de la caxa gran d'àlber, qui stava en la dita cambra, e se n'havia portat ab si fora lo dit alberc. E com lo dit frare Johan hagués hoïs ( sic) les dites coses, dix e respós que veritat era que ell se n'havia portat les dites copes culeretes e correga per obs de fer un càlser, mas que no se n'havia portat diners alguns, e lo dit en Serra li dix e respós que ell li daria tan com la dita defuncta tenia ara en sa malaltia pus de quatrecens florins, per què requerí mi, dit notari, que li fahés de allò menció en lo dit inventari”. APPV, Jaume Vinader, 9.535, 12 de agosto de 1443.

${ }^{38}$ APPV, Joan de Vera 1.445, 30 de junio de 1376. 
en los inventarios de los de individuos que podemos llamar cohabitadores, personas que no formaban parte ni del núcleo conyugal ni de la descendencia directa de la casa donde residían, pero que con toda seguridad utilizaban sus enseres aún sin poseerlos y que, por tanto, no se incluían en el inventario de sus bienes. El grupo más destacado es el de las viudas, cuyos inventarios incluyen raramente algo más que ropa y dinero líquido. Tras la muerte del marido algunas mujeres podían volver al mercado matrimonial con su dote, pero el destino de las más mayores solía ser la casa de algún familiar, y lo más normal era que sus posesiones fueran con ellas, como era el caso de Menga, cuyos bienes estaban en casa de su yerno Aparisi, hon la dita defuncta finà, o el de Beatriu, que había sido trasladada a casa de una mujer para haver cura de ella porque estaba vella e malalta ${ }^{39}$. Esta detección era posible incluso en los casos más complejos, como cuando los bienes del fallecido se habían trasladado de un lugar a otro. Es lo que ocurrió al morir el labrador Pere Alguayra, quien vivía con su mujer Joana y una hija pequeña en una alquería cercana a la ciudad de Valencia. A la muerte de Pere se unió el cada vez más cercano momento del parto de Joana, que esperaba otro hijo, lo que la llevó a mudarse a casa de un familiar en Russafa y a llevarse consigo los bienes de Pere. Cuando Joana se decidió a encargar el inventario de los enseres de su difunto esposo estos debían de hallarse tan entremezclados con los de la vivienda donde se habían trasladado que encargaba el listado para que pogués esser sabut quins ne quants béns possehien, es decir, cuáles y cuántos ${ }^{40}$.

No era sólo una cuestión de cohabitadores. El tipo de régimen matrimonial tenía implicaciones sobre la propiedad de los enseres en el momento de la defunción, y así, conllevaba diferencias entre los inventarios de hombres y mujeres. Como en muchos otros lugares de la Europa feudal, en el reino de Valencia la mujer aportaba una dote para la constitución del matrimonio, en metálico y en enseres domésticos, que debería recuperar tras la muerte del marido junto con el creix -la mitad del importe dotal aportado por éste-, siendo el resto de los bienes del difunto los que obtendrían los herederos. Ahora bien, mientras el varón viviera, los bienes dotales se consideraban suyos, pues él era quien debía cuidarlos y administrarlos ${ }^{41}$. Debe de ser por este motivo por el que es tan frecuente encontrar enseres específicamente descritos como de la dona en los inventarios de varones. Pero además, hay que pensar que para la viuda esta inclusión debía de cumplir un

\footnotetext{
${ }^{39}$ Para el inventario de Menga, APPV, Sancho Cornell, 13.070, 15 de septiembre de 1393. Para el de Beatriu, APPV, Jaume Vinader, 9.040, 19 de septiembre de 1441.

${ }^{40}$ Los bienes eran de ambos en virtud de su matrimonio en régimen de comunidad de bienes, de ahí que la fuente diga "possehien". APPV, Jaume Vinader, 9.531, 17 de noviembre de 1438

${ }^{41}$ Colón, Garcia 1970-2007, vol. V, pp. 17, 30, 63.
} 
papel positivo, que era el de listar los bienes de los que reclamaría su dote. Lo expresaba con claridad Bertomeua cuando mandaba listar los bienes de su marido en 1443: que per lo present inventari preiuhí algú no sia fet als dot e creix que deig haver e recobrar ne en los altres beneficis que haia en los béns del dit defunct ${ }^{42}$.

Los inventarios de varones incluían pues los bienes de la mujer, pero esto no ocurría a la inversa. Tanto si una mujer moría o no en la viudedad, lo que sus herederos obtendrían serían sus bienes dotales y también los parafernales o privativos, que según la ley del reino irían a todos los hijos de todos los matrimonios, y si no los tuviera, dos tercios serían para el dotador y un tercio para el marido ${ }^{43}$. No había razón, pues, para que los bienes del marido aparecieran en el inventario de la mujer, lo que explica que éste aporte una mayor sensación de vacío. No es el caso, sin embargo, de los inventarios que listaban los bienes de ambos cónyuges. Cuando el matrimonio se había llevado a cabo bajo régimen de comunidad de bienes o germania se listaban los bienes de ambos, aunque uno de ellos estuviera vivo. De la misma manera que los inventarios de varones bajo régimen dotal cumplirían la función de listar la dote de la mujer, estos inventarios de matrimonios en germania seguramente ayudarían a que el cónyuge superviviente y los hijos pudieran repartirse la herencia en dos mitades ${ }^{44}$.

Estas premisas se deducen desde la lógica de la ley foral, pero también desde los propios inventarios. Es lo que sugiere la figura 2, que se basa en una muestra de 75 inventarios de la villa de Morvedre del año 1348. Divididos entre aquellos de hombres, mujeres o ambos cónyuges en virtud de contratos de germania, cada grupo de inventarios se distribuye según la cantidad de bienes que tuvieran, desde menos de 10 a más de 80 ítems. Cuanto más hacia el exterior de la red se sitúe la distribución, mayor porcentaje de inventarios de un grupo determinado se concentra en la gama indicada ${ }^{45}$. Aunque este sistema no puede tener en cuenta la pertenencia a diferentes grupos sociales o niveles de riqueza familiar, que son los que última instancia hubieron de influir en la riqueza material de estos individuos, las distribuciones que se observan no parecen aleatorias, confirman las premisas anteriores y aportan unos órdenes

\footnotetext{
${ }^{42}$ AMV, Pere Pérez, 23-1, 13 de enero de 1443.

${ }^{43}$ Colón, Garcia 1970-2007, vol. V, pp. 26-41.

${ }^{44}$ Sobre la función económica de la dote y los contratos de germania véase Furió 1998.

${ }^{45}$ Se ha tomado la gama de bienes (número de ítems, o sea, de bienes diferentes) y no la cantidad (número de bienes sin más), una forma de análisis que se ha llevado a cabo en repetidas ocasiones, lo que permite comparaciones y referir a trabajos sobre sus límites: Bolòs, Sànchez-Boira 2014, vol. I, pp. 46 y ss.; Vries 2008, pp. 123-124; Schuurman 1980, pp. 25-26.
} 
de magnitud ${ }^{46}$. Puede apreciarse cómo la mayoría de inventarios de mujeres se concentran en la mitad derecha de la gráfica, es decir, en las gamas más bajas de ítems. Más de la mitad de estos inventarios recogían entre 10 y 40 ítems, sólo un $10 \%$ entre 40 y 50, y cerca de un tercio pasaba de ahí. Por el contrario, los inventarios de varones y aquellos que listaban las posesiones de ambos cónyuges se concentraban en las gamas más altas. Prácticamente dos tercios de los inventarios de los bienes de ambos cónyuges se reparten de manera bastante uniforme entre gamas de 30 a 50 bienes, y un $20 \%$ tenía más de eso. La mitad de los inventarios de varones se concentran en la misma franja de 30 a 50, pero sobre todo en la gama de los 51-60 ítems (30\%), mientras que menos de un tercio pasa de esa franja, y un $12 \%$ baja de ella.

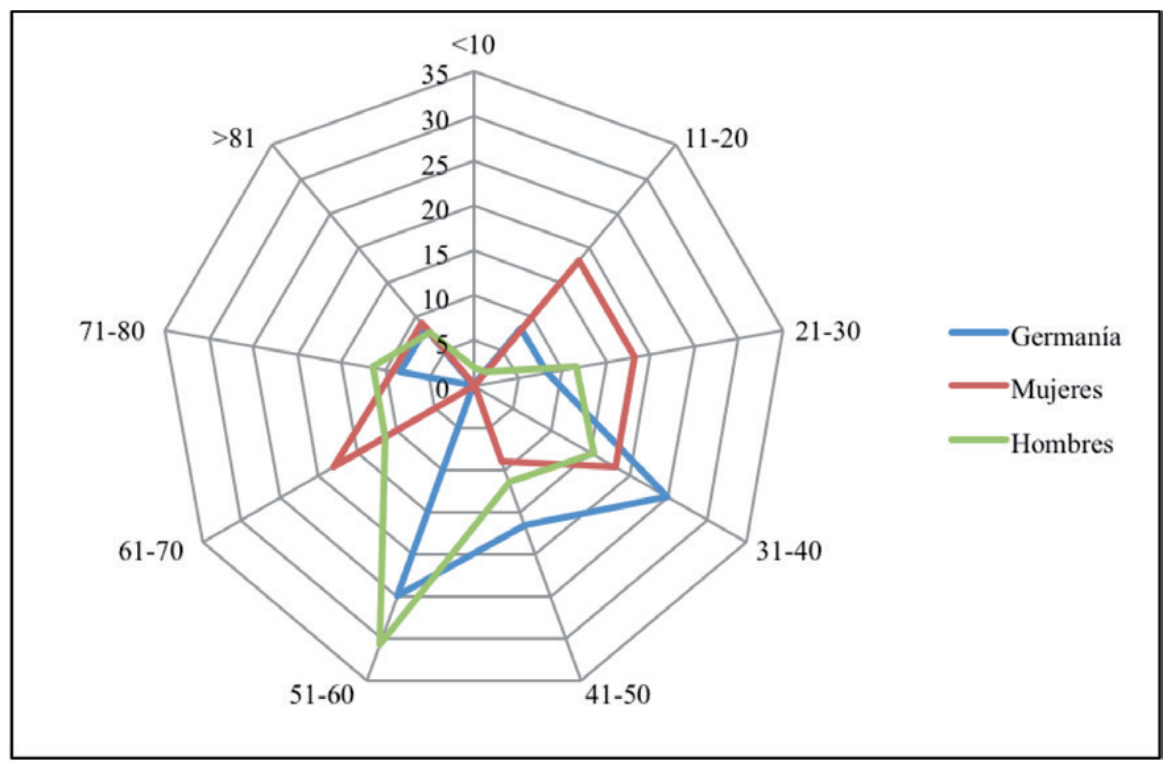

Fig. 2. Distribución de la gama de bienes en los inventarios de hombres, mujeres y matrimonios bajo régimen de comunidad de bienes o germania (Morvedre, 1348) ${ }^{47}$.

${ }^{46}$ Casi todos estos individuos constan como vicinus, aunque la naturaleza de sus bienes sugiere que se trata en general de campesinos y artesanos, los grupos mayoritarios de Morvedre en la época (Guinot 2007).

${ }^{47}$ La muestra está compuesta por 75 inventarios de bienes extraídos del protocolo de Domingo Joan del año 1348 (AMV, Domingo Joan, 1-1). De ellos, 52 inventarios eran de varones, 11 de mujeres y 12 bajo régimen de comunidad de bienes. Cada punta de la red representa una escala de 10 ítems. Cada línea interna representa un porcentaje sobre el total de cada grupo de inventarios. 
Puede decirse pues que los inventarios de varones y de ambos cónyuges se acercan más al interior doméstico que los de las mujeres, que por las particularidades del régimen dotal los confina a una mayor parcialidad. Ahora bien, no sólo el lugar del difunto dentro de la unidad familiar podía determinar lo que se inventariaba. Existían mecanismos jurídicos que podían detraer algunos bienes del conjunto de la herencia, como era el caso de los legados especiales de testamentos y codicilos, que solían realizarse para pagar la dote de la futura viuda. Entonces el notario sencillamente ignoraba estos bienes, como cuando Jaume Vinader se limitó a anotar los bienes inmuebles de Joana, la hija y heredera del labrador Joan Diprés, com lo moble sia de la dita Francesca [su mujer] per legat especial ${ }^{48}$, el mismo motivo por el cual el notario Bernat Gil pasaba por alto los bienes que el marido de Mirona tenía en la cambra de su casa ${ }^{49}$.

Pero además, de manera menos conocida, ocasionalmente los inventarios dejaban de lado objetos cuyo valor fuera irrisorio. Así lo evidencia el contraste de estos con sus correspondientes almonedas o encants, las subastas públicas de los bienes del difunto que ordenaban los albaceas para cubrir sus deudas, los gastos de la sepultura y otras demandas pías ${ }^{50}$. La tabla 1 muestra el ejemplo de diversos utensilios de cocina que no aparecían en los inventarios de tres campesinos de la primera mitad del siglo XV, pero sí entre los bienes subastados. Se trata de objetos hechos de todo tipo de materiales, como madera y cerámica en el caso de platos (talladors), morteros (morters), lebrillos (llibrells), cucharas (culleres) y artesas (pasteres), pero también de metal y vidrio, presente en espetos (asts) y botellas (ampolles). En ningún caso el precio de estos objetos llegaba a la frontera de un sueldo. El más caro era el lebrillo de Miquel Morella, y costaba 10 dineros, y era el único objeto vendido de forma individual. El resto se compraron en grupo, lo que implica que sus precios por unidad hubieron de ser extraordinariamente bajos. Los tres ast de ferre de Andreu Beneyto valdrían 5 dineros cada uno, mientras que las cuatro escudillas de Miquel Morella poco más de 2. Asumiendo que las siete escudillas, la cuchara, el mortero y el mazo de Miquel Morella hubieran valido lo mismo, cada objeto habría valido apenas medio dinero.

\footnotetext{
${ }^{48}$ APPV, Jaume Vinader 9.540, 10 de julio de 1450.

49 "Hec sunt illa bona que invenimus fore dicti defuncti (...) salvo tamen quod de bonis in camera dicti defuncti sunt inventarium non est fattum cum omnia bona quecumque sint in camera fuerint mei dicte Mirone vigore legati michi in quodam codicillo dacti per defuctum superius declaratum". APPV, Bernat Gil, 331, 2 de septiembre de 1400.

${ }^{50}$ Sobre las almonedas valencianas véase García-Marsilla 2008.
} 
Tabla 1. Algunos bienes ignorados en los inventarios de tres campesinos valencianos del siglo $\mathrm{XV}$, con sus respectivos precios en diners (d) y sous (s).

\begin{tabular}{|c|c|c|c|c|c|}
\hline \multicolumn{2}{|c|}{ NICOLAU AM (1425) } & \multicolumn{2}{|c|}{$\begin{array}{c}\text { ANDREU BENEYTO } \\
(1428)\end{array}$} & \multicolumn{2}{|c|}{ MIQUEL MORELLA (1435) } \\
\hline BIENES & PRECIO & BIENES & PRECIO & BIENES & PRECIO \\
\hline 2 librells & $9 \mathrm{~d}$ & $\begin{array}{l}3 \text { asts de ferre } \\
\text { migancers }\end{array}$ & $1 \mathrm{~s} 3 \mathrm{~d}$ & $\begin{array}{l}1 \text { morter de terra, boix } \\
\text { e cullera de fust e } 7 \\
\text { escudelles de terra }\end{array}$ & $6 \mathrm{~d}$ \\
\hline $\begin{array}{l}3 \text { talladors } \\
\text { pintats }\end{array}$ & $7 \mathrm{~d}$ & & & $\begin{array}{l}2 \text { ampolles miganceres } \\
\text { e } 2 \text { xiques }\end{array}$ & $10 \mathrm{~d}$ \\
\hline \multirow{4}{*}{$\begin{array}{l}1 \text { cabaç ab } \\
\text { diverses } \\
\text { escudelles }\end{array}$} & $7 \mathrm{~d}$ & & & $\begin{array}{l}2 \text { asts de ferre, } 1 \\
\text { migancer, altre xich }\end{array}$ & $1 \mathrm{~s}$ \\
\hline & & & & $\begin{array}{l}4 \text { escudelles } \\
\text { miganceres }\end{array}$ & $9 d$ \\
\hline & & & & 1 librell de pastar & $10 \mathrm{~d}$ \\
\hline & & & & $\begin{array}{l}3 \text { talladors de fust } \\
\text { migancers }\end{array}$ & $7 d$ \\
\hline
\end{tabular}

Fuente: Almonedas de Nicolau Am (APPV, Jaume Vinader, 9.518, 2 de mayo de 1425), Andreu Beneyto (APPV, Jaume Vinader, 9.526, 20, 25 de octubre y 7 diciembre de 1428) y Miquel Morella (APPV, Domènec Barreda, 6.430, del 5 al 10 de febrero de 1435).

El hecho de que se ignoraran estos objetos no representa algo inédito en comparación con otros casos de la Europa feudal. Ocurría en algunas zonas de Francia del siglo XIV y, en este último caso, los propios notarios especificaban que algunos de estos bienes, como los de cerámica, se ignoraban por su escaso valor ${ }^{51}$. No obstante, en el caso valenciano esta forma de obviar bienes es más difícil de explicar, porque los inventarios sí listan habitualmente este tipo de bienes dedicados al procesado y servicio de alimentos ${ }^{52}$. Quizás los propios familiares de los difuntos consideraran que no valía la pena heredar estos bienes, pero desde luego sí venderlos para cubrir diversos gastos. En cualquier caso, esto añade un ingrediente de incertidumbre al tratar este tipo de enseres que hay que valorar al utilizar la fuente.

\footnotetext{
${ }^{51}$ Piponnier 1987, p. 236.

${ }^{52}$ Véase Almenar 2014, trabajo basado íntegramente en inventarios post mortem y almonedas valencianas para el estudio de este tipo de bienes.
} 
A la luz de todas estas circunstancias, puede decirse, en definitiva, que no todos los inventarios revelan el interior doméstico de la misma manera. La fijación por los bienes de un individuo, y no por los de la casa, ha de considerarse la característica más decisiva de ello, y de hecho, podía llevar a que se incluyeran en el inventario bienes que ni siquiera estaban en la vivienda, pero que lo habían estado. Por ejemplo, objetos vendidos entre la defunción y la redacción del inventario, o bienes empeñados que se hallaban en casa de otras personas, como la correa de plata de Miquel Garcia, que manllevaren a obs de la malatia del dit defunct ${ }^{53}$. Pero aún más, los inventarios podían incluir bienes del difunto que jamás habían estado en la casa, de los cuales los albaceas quizás no sabían exactamente qué eran, pero sabían de su existencia, seguían siendo posesión del difunto y tenían derecho a heredarlos. El inventario entonces no sólo dejaba constancia de que existían, sino también de que se había ordenado traerlos para anotarlos. Así lo hacía la viuda Beneguda y Pere, el futuro tutor de sus hijos, con los bienes del difunto Gabriel Císcar, en cuyo inventario no sólo se recogían sus bienes en Valencia, sino que se ordenaba anotar los que tenía en Vilajoiosa ${ }^{54}$; o los herederos de Pere Marrades, quienes sabían de la existencia de ciertos bienes del difunto en Barcelona, por lo que hubieron de mandar a un notario como procurador para recoger esos bienes en un ápoca, que seguramente los herederos recibirían para valorar si valía la pena reclamarlos ${ }^{55}$.

Parece pues que lo que se incluía en los inventarios era mucho más producto del oído que de vista del notario, que era un personaje pasivo ante la identificación de bienes que hacían los familiares del difunto, la cual él se limitaba a escribir. Estos podían asegurar así la exhaustividad del inventario, de la identificación de bienes dentro y fuera de la casa, pero también hay que pensar que esto con toda seguridad podía comportar todo lo contrario, la omisión intencionada o accidental de bienes diversos. No hay olvidar que ningún inventario es una "instantánea" aséptica, y que la fuerza del deseo de heredar los bienes, materializada en la información que proporcionaban los familiares del difunto al notario, puede ir tanto a favor como en contra del historiador del consumo.

\footnotetext{
${ }^{53}$ APPV, Joan de Vera, 1446, 17 de febrero de 1382.

${ }^{54}$ APPV, Jaume Vinader 9.533, 30 de marzo de 1440.

${ }^{55}$ APPV, Pere Roca, 24.051, 17 de junio de 1398.
} 


\section{5. ¿UNA SOCIEDAD DEL INVENTARIO?}

Una de las problemáticas más asumidas del inventario post mortem es la de ser un documento socialmente sesgado. Pardailhé-Galabrun los valoraba como "un acte de riche", y muchos historiadores han coincidido en que "su alcance no llega mucho más allá de los grupos medios" ${ }^{16}$. Pero, en el caso de la Valencia medieval, es muy difícil pensar que los inventarios fueran un instrumento inalcanzable para alguna clase social. Los primeros inventarios pueden localizarse ya en los protocolos notariales de las décadas de 12801290, prácticamente cincuenta años después de la fundación del reino, y los dueños de los bienes listados abarcan miembros del patriciado urbano, artesanos y hasta campesinos de los alrededores inmediatos de la ciudad ${ }^{57}$. No se trata de un hecho exclusivo de la ciudad de Valencia, sino que también pueden documentarse inventarios de finales del siglo XIII en una pequeña localidad del sur del reino como Cocentaina, de población eminentemente rural $^{58}$. Todo esto hace razonable pensar que, ya desde los orígenes del reino, los inventarios valencianos estuvieron tan extendidos geográfica y socialmente como la misma práctica notarial.

Esta impresión se confirma para épocas en las que conservamos una cantidad mayor de inventarios. Si para finales del siglo XIII podemos contar con una decena, durante el siglo XIV hay que hablar ya de cientos. Si reparamos en una muestra de cerca de 200 de estos documentos de la segunda mitad del siglo XIV (tabla 2), resulta evidente lo variada que es la extracción social de los difuntos. La mayoría de estos inventarios contenían los bienes de miembros del artesanado, el patriciado y el campesinado de la huerta y la propia ciudad, por ese orden. Prácticamente 1 de cada 5 inventarios corresponde a uno de estos tres sectores, seguidos de eclesiásticos y mercaderes en proporciones de un $6 \%$ entre ambos. Hay que destacar que una gran cantidad de difuntos que sobrepasa el $60 \%$ no eran incluidos dentro de ninguna categoría social específica, pero dado que la mayoría de ellos provenían de la villa de Morvedre, cuya composición social se repartía mayoritariamente entre campesinos y artesanos, se refuerza en todo caso la impresión de estos dos grupos como parte de los más representados ${ }^{59}$. Lo

${ }^{56}$ Para las citas, Pardailhé-Galabrun 1989, pp. 42-43; Vries 2008, p. 126. Muchos historiadores del norte y sur de Europa han hecho eco de este límite: Overton, et al. 2004, pp. 22-28; Torras, Yun 1999, pp. 33-34; Sobrado 2003, p. 834; Ramos 2011, p. 26.

${ }^{57}$ Para la ciudad de Valencia véanse, por ejemplo, los protocolos del ARV de Jaume Castell y Jaume Riquer.

${ }^{58}$ Ferragud 2003, pp. 215-218.

${ }^{59}$ Guinot 2007. 
mismo ocurre con los que sólo eran denominados vecino (vehî), de la ciudad de Valencia en su mayoría, que muy probablemente formarían parte del sector artesanal.

Tabla 2. Extracción social de los difuntos en inventarios de la segunda mitad del siglo XIV (1348-1400) $)^{60}$

\begin{tabular}{ccc} 
PERFIL SOCIAL & INVENTARIOS & PORCENTAJE $(\%)$ \\
\hline \hline Oficios & 25 & 13,2 \\
Ciudadano & 13 & 6,9 \\
Labrador & 9 & 4,7 \\
Mercader & 6 & 3,1 \\
Eclesiásticos & 5 & 2,6 \\
Nobleza & 2 & 1,1 \\
Mudéjar/Judío & 2 & 1,1 \\
Oficial & 1 & 0,5 \\
\hline Vehí & 40 & 21,2 \\
Habitant & 6 & 3,1 \\
Commorant & 2 & 1,1 \\
Sin especificar & 77 & 40,9 \\
\hline Total & 188 & 100
\end{tabular}

Fuente: Todos los inventarios conservados entre 1348 y 1400 en el AMV y APPV.

Amplios sectores de la sociedad medieval valenciana recurrían desde épocas muy tempranas al inventario de bienes, y esta sensación aumenta cuantitativamente conforme uno se acerca al final de la Edad Media. La figura 3 despliega la muestra de inventarios anterior año por año, poniéndola en relación con el número de protocolos conservados. La tendencia que sigue la cantidad anual de inventarios (línea roja) muestra cierto aumento, irregular pero progresivo, de la cantidad de inventarios conservados hacia finales del

\footnotetext{
${ }^{60}$ La cantidad total de inventarios en esta cronología y archivos es de 200 , si bien 12 correspondían a ejemplares tan dañados o incompletos que no aparecía referencia alguna al propietario de los bienes.
} 
siglo XIV. No obstante, esta impresión es fruto de la mayor conservación de los registros notariales en la misma cronología (línea azul). Hay que reparar en que la línea roja casi nunca sobrepasa a la azul, lo que quiere decir que anualmente se conservan más protocolos que inventarios, o lo que es lo mismo, que raramente se llega a la media de 1 inventario por protocolo y año. Además, la experiencia documental es que, al contrario que en períodos más tardíos, uno puede explorar muchos de estos registros notariales sin encontrar ni un solo inventario.

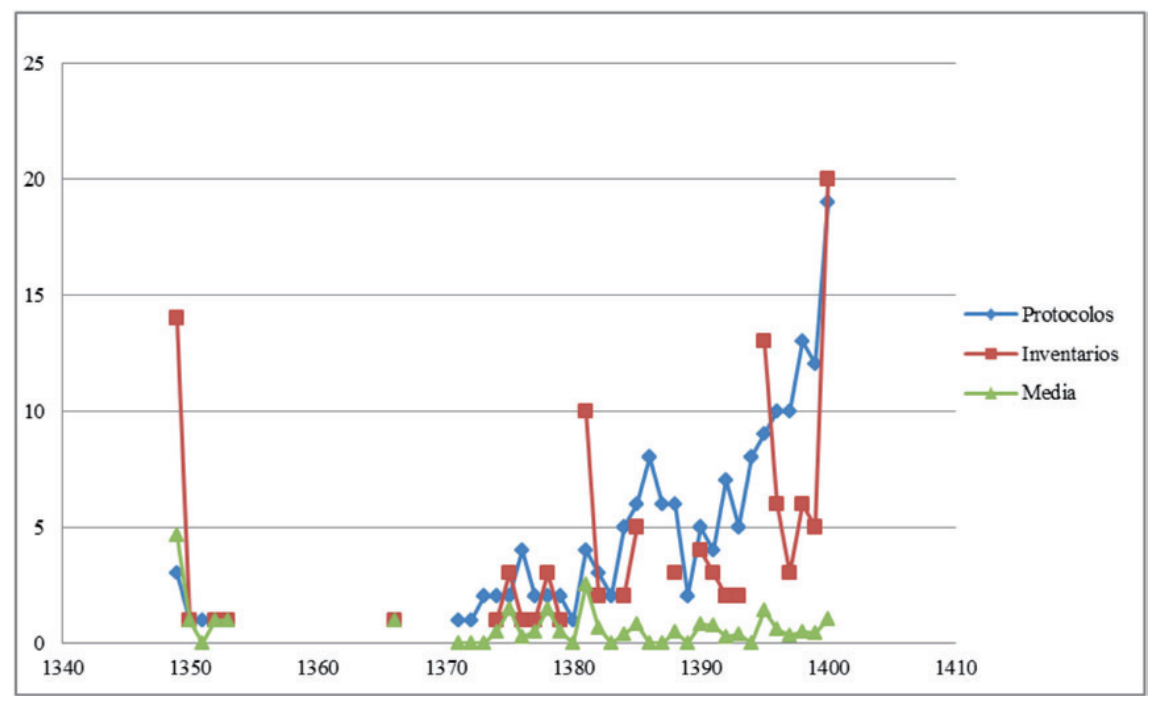

Fig. 3. Cantidad anual de inventarios y protocolos conservados en dos archivos valencianos $(1349-1400)^{61}$

Es en el tránsito del siglo XIV al XV cuando parece que los inventarios comenzaron a convertirse en un documento más frecuente. Lo sugiere la comparación del corpus anterior con una muestra de la primera mitad del siglo XV (figura 4). Si en el período que hemos explorado hasta ahora se incluían todos los protocolos notariales conservados (un total de 222, de 33 notarios), desde 1400 sólo se añaden las series de 2 notarios (46 protocolos). Sólo esos dos notarios, con un protocolo anual en ambos casos, ya ofrecen

${ }^{61}$ La gráfica se basa en la totalidad de los inventarios y protocolos conservados en el APPV y AMV entre 1349 y 1400. Para evitar distorsiones se han excluido los inventarios de 1348, 86 en total, algo absolutamente fuera de lo común que debe de estar relacionado con las secuelas de la Guerra de la Unión (1347-1348) y de la Peste Negra. 
una media muy por encima de la de los cincuenta años previos, de más de 3 inventarios por y año de media, es decir, el triple, o en términos absolutos, 148 inventarios frente a los 200 del período anterior. De hecho, es difícil no encontrar ningún inventario en los protocolos de este período, y teniendo en cuenta que éstas son las cantidades proporcionadas por dos únicos notarios, es seguro que las cantidades sean muchísimo mayores si añadimos más notarios. Teniendo en cuenta que para la primera mitad del siglo XV se conservan unos 1.960 protocolos sólo en el Archivo de Protocolos del Patriarca de Valencia, si la media de estos notarios fuera aplicable al resto de protocolos podríamos estimar la existencia de unos 5.900 inventarios para esa mitad del siglo. Esto sin contar por supuesto los protocolos de otros archivos de la ciudad de Valencia o de localidades del territorio valenciano, y sin contar tampoco los de la segunda mitad del siglo XV, cuando la cantidad de protocolos es aún más alta.

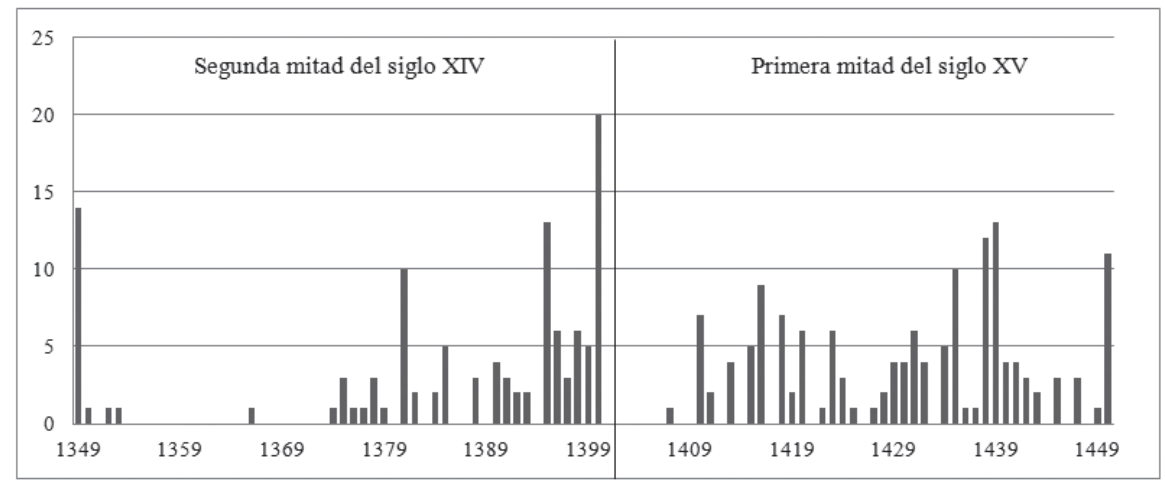

Fig. 4. Comparación de las cantidades de dos muestras de inventarios: segunda mitad del siglo XIV vs. primera mitad del siglo $\mathrm{XV}^{62}$.

Por otro lado, para estos primeros cincuenta años del siglo XV la extracción social de los difuntos puede conocerse mejor, y las proporciones obtenidas son muy similares al período anterior (tabla 3). Son los artesanos y los campesinos los sectores más representados, aglutinando más de la mitad de la muestra, seguido por los miembros del patriciado. Si contamos estos

${ }^{62}$ La primera sección de la comparación se basa en todos los inventarios conservados en el AMV y el APPV entre 1349 y 1400. Para la segunda sección, se incluyen únicamente los inventarios de los notarios Domènec Barreda (24 protocolos entre 1407-1445), y Jaume Vinader (22 protocolos entre 1416-1450). 
últimos junto con los de artesanos y campesinos, puede decirse que dos de cada tres inventarios (un 68\%) pertenecen a una de estas tres categorías. El otro tercio lo constituyen desde miembros de la clase mercantil hasta la nobleza, tal y como ocurría en el período anterior.

Tabla 3. Extracción social de los difuntos en inventarios de la primera mitad del siglo XV (1401-1450) ${ }^{63}$

\begin{tabular}{ccc} 
PERFIL SOCIAL & INVENTARIOS & PORCENTAJE (\%) \\
\hline Oficios & 47 & 35,1 \\
Labrador & 27 & 20,1 \\
Ciudadano & 18 & 13,4 \\
Eclesiásticos & 8 & 5,9 \\
Mercader & 6 & 4,4 \\
Oficial & 3 & 2,2 \\
Nobleza & 1 & 0,7 \\
Mudéjar/Judío & 0 & 0 \\
\hline Vehí & 10 & 7,4 \\
Habitant & 2 & 1,4 \\
Commorant & 0 & 0 \\
Sin especificar & 12 & 8,9 \\
\hline Total & 134 & 100
\end{tabular}

Fuente: Todos los inventarios de los protocolos notariales de Domènec Barreda (24 registros entre 1407-1445) y Jaume Vinader (22 registros entre 1416-1450).

Hay que plantear, pues, la posibilidad de que la cantidad significativamente mayor de inventarios que aparecen en el siglo XV no sea sólo una cuestión de conservación. Es precisamente en el paso del siglo XIV al $\mathrm{XV}$ cuando los fueros incorporan un privilegio del rey Martín I estableciendo los salarios pagados a los notarios por cierto tipo de documentos, entre los que se incluyen los inventarios y almonedas, con un precio máximo de 4 sueldos por full $^{64}$. Esto tiene una importancia fundamental teniendo en

\footnotetext{
${ }^{63}$ La cantidad total de inventarios de los dos notarios en los que se basa la tabla en este período es de 148, si bien 14 correspondían a ejemplares tan dañados o incompletos que no aparecía referencia alguna al propietario de los bienes.

${ }^{64}$ Taraçona 1580,p. 157.
} 
cuenta que el coste del inventario ha sido uno de los argumentos historiográficos a favor de su supuesto sesgo social. Se ha llegado a afirmar que se podría hablar de la existencia de una relación entre el costo del acta y la selección social, que el coste de este tipo de acta era muy elevado para los sectores populares ${ }^{65}$. Sin embargo, la experiencia de los inventarios valencianos es que todas las clases sociales accedían a él, y esto tenía un correlato en sus precios, que podemos conocer relativamente bien. Muchos albaceas no pagaban el inventario en el momento de su redacción, con lo que los notarios anotaban un debet al margen del documento, y alguna vez añadían la cantidad debida. Los precios de las almonedas se anotaban con mucha más frecuencia, apareciendo como parte de los gastos de la subasta (messions), lo que implica que era frecuente pagar al notario con la propia suma obtenida de la venta. Así pues, se ha podido extraer el coste de 23 inventarios y almonedas, cuyos precios seguramente serían similares o idénticos, pues el máximo de 4 sueldos por full se aplicaba a ambos. Hay que destacar que no puede saberse con certeza cuánto era un full, aunque se ha llegado a la conclusión de que se trataría de una hoja de papel completa, o sea dos caras de folio, y cuando se ocupaba una cara se computaba como medio full.

Los resultados, en una cronología dilatada que abarca desde el último tercio del siglo XIV a mediados del XV, pueden verse en la tabla 4. Los inventarios se pagaron en general a entre 1 y 12 sueldos, aunque las cantidades más repetidas estaban entre 3 y 6 a lo largo de todo el período. Ahora bien, si nos centramos en el precio por folio, parece que desde la mitad del siglo XV en adelante el precio del documento descendió hasta entre 1'5 y 2'5 sueldos, cuando antes muy raramente bajaba de los 3-4 sueldos. Lo destacable, en definitiva, es que la mayoría de las tarifas se situaban en estándares perfectamente asequibles para la época. El sueldo medio de un asalariado entre finales del siglo XIV y mediados del XV en la ciudad de Valencia podía oscilar entre los 25 y los 35 dineros al día, o sea entre cerca de 2 y 3 sueldos $^{66}$. Desde este punto de vista, la mayoría de los inventarios de esta tabla podían haberse pagado con el esfuerzo de un día de trabajo, algo que la lógica dicta como absolutamente admisible para acceder a la totalidad de los bienes de una vida.

${ }^{65}$ Sobrado 2003, ambas frases en p. 834.

${ }^{66}$ Hamilton 1936, pp. 273-280. 
Tabla 4. Relación de precios de diversos inventarios y almonedas valencianas $(1376-1450)^{67}$

\begin{tabular}{|c|c|c|c|c|c|c|c|c|}
\hline Doc. & AÑO & DIFUNTO/A & CONDICIÓN & $\begin{array}{l}\text { ORDENA EL } \\
\text { DOCUMENTO }\end{array}$ & NOTARIO & PRECIO & FULLS & $\begin{array}{r}\text { PRECIO/ } \\
\text { FULL } \\
\end{array}$ \\
\hline Alm. & 1376 & $\begin{array}{l}\text { Antoni } \\
\text { Jordà }\end{array}$ & & Un paraire & Lluís Llopis & $12 \mathrm{~s}$ & 14 & $<1 \mathrm{~s}$ \\
\hline Alm. & 1386 & Caterina & & & Lluís Llopis & $2 \mathrm{~s}$ & 2 & $1 \mathrm{~s}$ \\
\hline Inv. & 1388 & $\begin{array}{l}\text { Arnau } \\
\text { García }\end{array}$ & \begin{tabular}{|l|} 
Llaurador de \\
Massarojos
\end{tabular} & Su mujer & $\begin{array}{l}\text { Arnau } \\
\text { Garcia }\end{array}$ & $5 \mathrm{~s} 6 \mathrm{~d}$ & 1,5 & $3 \mathrm{~s} 8 \mathrm{~d}$ \\
\hline Alm. & 1425 & $\begin{array}{l}\text { Pere } \\
\text { Negre }\end{array}$ & Ciutadà & $\begin{array}{l}\text { Joan Bonet y } \\
\text { Francesc Torres, } \\
\text { ciutadans }\end{array}$ & $\begin{array}{c}\text { Arnau } \\
\text { Almirall }\end{array}$ & $4 \mathrm{~s} 6 \mathrm{~d}$ & 1 & $4 \mathrm{~s} 6 \mathrm{~d}$ \\
\hline Alm. & 1425 & Joana & Vella dona & & $\begin{array}{c}\text { Arnau } \\
\text { Almirall }\end{array}$ & $4 \mathrm{~s}$ & 0,5 & $8 \mathrm{~s}$ \\
\hline Alm. & 1413 & $\begin{array}{l}\text { Pere } \\
\text { Sanxo }\end{array}$ & $\begin{array}{l}\text { Llaurador de } \\
\text { Valencia }\end{array}$ & $\begin{array}{l}\text { Joan Ferrando, } \\
\text { ferrer; y } \\
\text { Jaume Fortea, } \\
\text { llaurador }\end{array}$ & $\begin{array}{l}\text { Domènec } \\
\text { Barreda }\end{array}$ & $1 \mathrm{~s} 6 \mathrm{~d}$ & 0,5 & $3 \mathrm{~s}$ \\
\hline Alm. & 1424 & $\begin{array}{c}\text { Francesc } \\
\text { Pelegrí }\end{array}$ & $\begin{array}{l}\text { Corredor } \\
\text { d'orella }\end{array}$ & $\begin{array}{l}\text { Jaume Peralada, } \\
\text { calderer. }\end{array}$ & $\begin{array}{l}\text { Domènec } \\
\text { Barreda }\end{array}$ & $7 \mathrm{~s}$ & 4 & $1 \mathrm{~s} 9 \mathrm{~d}$ \\
\hline Inv. & 1430 & Caterina & $\begin{array}{l}\text { Mujer de } \\
\text { procurador } \\
\text { fiscal del rey }\end{array}$ & $\begin{array}{l}\text { Bernat } \\
\text { Burguera, } \\
\text { llaurador de } \\
\text { Patraix } \\
\end{array}$ & $\begin{array}{l}\text { Domènec } \\
\text { Barreda }\end{array}$ & $\begin{array}{r}5 \mathrm{~s} \\
10 \mathrm{~d}\end{array}$ & 1 & $5 \mathrm{~s} 10 \mathrm{~d}$ \\
\hline Alm. & 1431 & $\begin{array}{l}\text { Vicent } \\
\text { Vives }\end{array}$ & $\begin{array}{l}\text { Vecino de } \\
\text { Patraix }\end{array}$ & $\begin{array}{l}\text { Francesca (su } \\
\text { mujer) }\end{array}$ & $\begin{array}{c}\text { Domènec } \\
\text { Barreda }\end{array}$ & $3 \mathrm{~s}$ & 1 & $3 \mathrm{~s}$ \\
\hline Alm. & 1434 & Caterina & $\begin{array}{l}\text { Mujer de } \\
\text { obrer de vila }\end{array}$ & $\begin{array}{l}\text { Pasqual } \\
\text { Navarro, } \\
\text { llaurador de } \\
\text { Quart }\end{array}$ & $\begin{array}{l}\text { Domènec } \\
\text { Barreda }\end{array}$ & $9 \mathrm{~s}$ & 3,5 & $2 \mathrm{~s} 6 \mathrm{~d}$ \\
\hline Alm. & 1435 & Caterina & $\begin{array}{l}\text { Mujer de } \\
\text { vecino de } \\
\text { Alfara }\end{array}$ & $\begin{array}{l}\text { Simó Aparici, } \\
\text { llaurador de } \\
\text { Benifaraig; } \\
\text { y Domingo } \\
\text { Aparici, } \\
\text { llaurador de } \\
\text { Valencia }\end{array}$ & $\begin{array}{l}\text { Domènec } \\
\text { Barreda }\end{array}$ & $6 s$ & 3 & $2 \mathrm{~s}$ \\
\hline
\end{tabular}

${ }^{67}$ Algunas almonedas especificaban que se habían pagado junto con el inventario de bienes, dando una cifra total. En esos casos figuran en la tabla con la abreviatura "Inv.+Alm.", cuyo valor se ha dividido por el número de folios de ambos documentos, y por tanto, se ha asumido que su precio sería prácticamente idéntico, como la propia tabla refleja para algunos casos. 


\begin{tabular}{|c|c|c|c|c|c|c|c|c|}
\hline Alm. & 1437 & Maria & \begin{tabular}{|l|} 
Mujer de \\
llaurador de \\
Valencia \\
\end{tabular} & $\begin{array}{l}\text { Bertomeu } \\
\text { Conquist, } \\
\text { teixidor }\end{array}$ & $\begin{array}{l}\text { Domènec } \\
\text { Barreda }\end{array}$ & $3 \mathrm{~s}$ & 2 & $1 \mathrm{~s} 6 \mathrm{~d}$ \\
\hline Alm. & 1438 & $\begin{array}{l}\text { Pere } \\
\text { Cirera }\end{array}$ & Ciutadà & & $\begin{array}{l}\text { Domènec } \\
\text { Barreda }\end{array}$ & $3 \mathrm{~s}$ & 2 & $1 \mathrm{~s} 6 \mathrm{~d}$ \\
\hline Inv. & 1438 & $\begin{array}{c}\text { Pere } \\
\text { Alguayra }\end{array}$ & \begin{tabular}{|l|} 
Llaurador de \\
Valencia
\end{tabular} & Joana (su mujer) & $\begin{array}{l}\text { Jaume } \\
\text { Vinader }\end{array}$ & $3 \mathrm{~s}$ & 1,5 & $2 \mathrm{~s}$ \\
\hline Alm. & 1440 & Aldonça & $\begin{array}{l}\text { Mujer de } \\
\text { argenter }\end{array}$ & $\begin{array}{l}\text { Jaume Jofré, } \\
\text { apotecari }\end{array}$ & $\begin{array}{l}\text { Jaume } \\
\text { Vinader }\end{array}$ & $3 \mathrm{~s}$ & 1,5 & $2 \mathrm{~s}$ \\
\hline Inv. & 1441 & Beatriu & Anciana & $\begin{array}{l}\text { Pasquala (mujer } \\
\text { que la cuidaba) }\end{array}$ & $\begin{array}{l}\text { Jaume } \\
\text { Vinader }\end{array}$ & $1 \mathrm{~s} 6 \mathrm{~d}$ & 1 & $1 \mathrm{~s} 6 \mathrm{~d}$ \\
\hline $\begin{array}{l}\text { Inv.+ } \\
\text { Alm. }\end{array}$ & 1441 & $\begin{array}{l}\text { Alfonço } \\
\text { Gutèriz }\end{array}$ & Carnicero & Joana (su mujer) & $\begin{array}{l}\text { Jaume } \\
\text { Vinader }\end{array}$ & $3 \mathrm{~s}$ & 2 & $1 \mathrm{~s} 6 \mathrm{~d}$ \\
\hline $\begin{array}{l}\text { Inv.t } \\
\text { Alm. }\end{array}$ & 1445 & $\begin{array}{l}\text { Gaspar } \\
\text { Valls }\end{array}$ & Paraire & $\begin{array}{l}\text { Su mujer y su } \\
\text { padre }\end{array}$ & $\begin{array}{l}\text { Jaume } \\
\text { Vinader }\end{array}$ & $6 \mathrm{~s}$ & 7,5 & $<1 \mathrm{~s}$ \\
\hline Inv. & 1449 & $\begin{array}{l}\text { Llorenç } \\
\text { Paleres }\end{array}$ & Ciutadà & $\begin{array}{l}\text { Úrsula (su } \\
\text { mujer) }\end{array}$ & $\begin{array}{c}\text { Jaume } \\
\text { Vinader }\end{array}$ & $6 \mathrm{~s}$ & 0,5 & $12 \mathrm{~s}$ \\
\hline Inv. & 1450 & Elionor & $\begin{array}{l}\text { Mujer de } \\
\text { mercader }\end{array}$ & $\begin{array}{l}\text { Francesc Joan, } \\
\text { mercader; } \\
\text { Bernat Ballester, } \\
\text { calçater } \\
\end{array}$ & $\begin{array}{l}\text { Jaume } \\
\text { Vinader }\end{array}$ & $6 \mathrm{~s}$ & 1,5 & $4 \mathrm{~s}$ \\
\hline Inv. & 1450 & $\begin{array}{c}\text { Bertomeu } \\
\text { Terol } \\
\end{array}$ & Pescador & $\begin{array}{l}\text { Yolanda (su } \\
\text { mujer) }\end{array}$ & $\begin{array}{c}\text { Jaume } \\
\text { Vinader }\end{array}$ & $1 \mathrm{~s} 6 \mathrm{~d}$ & 1 & $1 \mathrm{~s} 6 \mathrm{~d}$ \\
\hline Inv. & 1450 & Isabel & $\begin{array}{l}\text { Mujer de } \\
\text { teixidor de } \\
\text { fustanys. }\end{array}$ & $\begin{array}{l}\text { Madona Felipa } \\
\text { (su madre) }\end{array}$ & $\begin{array}{l}\text { Jaume } \\
\text { Vinader }\end{array}$ & $1 \mathrm{~s} 6 \mathrm{~d}$ & 1 & $1 \mathrm{~s} 6 \mathrm{~d}$ \\
\hline Inv. & 1450 & $\begin{array}{l}\text { Alfonso } \\
\text { de Toledo }\end{array}$ & $\begin{array}{l}\text { Bracer, } \\
\text { vecino de } \\
\text { Valencia }\end{array}$ & $\begin{array}{l}\text { Caterina (su } \\
\text { mujer) Joan } \\
\text { Viana, teixidor } \\
\text { (albacea) }\end{array}$ & $\begin{array}{l}\text { Jaume } \\
\text { Vinader }\end{array}$ & $1 \mathrm{~s} 6 \mathrm{~d}$ & 1 & $1 \mathrm{~s} 6 \mathrm{~d}$ \\
\hline
\end{tabular}

Fuente: APPV, Lluís Llopis, 26.318, 28.473; AMV, Arnau Almirall, 22-1; APPV, Domènec Barreda, 6.421, 6.425, 6.426, 6.427, 6.429, 6.430, 6.431, 6.432; APPV, Jaume Vinader, 9.531, 9.533, 9.536, 9.040, 9.539, 9.540.

Más que el precio del documento, lo que debía ser fundamental es que existiera algo que dejar en herencia, y luego, razones por las que inventariar los bienes. Nada había más básico para estimular la redacción del inventario que la existencia de objetos que pudieran codiciarse. Por ello, la riqueza de los individuos, que no la clase social, sí debía de provocar que los sectores más humildes encargaran menos inventarios, pero que aún así lo hicieran si lo 
necesitaban ${ }^{68}$. Llevando un paso más lejos este argumento, quizás el hecho de que parezca que se ordenaron más inventarios durante el siglo XV que el XIV sea resultado del propio aumento del nivel de vida, muestra de una sociedad que acumulaba más y mejores bienes. En cualquier caso, aunque en desiguales proporciones, la práctica del listado de los bienes llegaba a todas las clases y estratos sociales, lo que lleva a plantearse la Valencia bajomedieval como una verdadera sociedad del inventario. Una sociedad que no era más que la consecuencia de la amplia difusión del notariado, una característica que compartía con los otros países de la Corona de Aragón y, en definitiva, con los de la Europa mediterránea.

\section{CONCLUSIÓN}

Los inventarios post mortem de la Valencia medieval son mucho más que documentos curiosos y pintorescos. No sólo se trata de uno de los casos más antiguos y abundantes de este tipo de documentación procedente de la Europa anterior al siglo XVI, sino que superan muchos de los límites de representatividad básicos con los que se han encontrado los historiadores de otros países, desde la propia cronología, que cubre de manera continua los últimos tres siglos de la Edad Media, a los grupos sociales que los solicitaban, que permite aproximar el consumo doméstico de prácticamente cualquier sector de la sociedad. Esto significa que su estudio seriado proporcionaría unos resultados que no serían únicamente estimables para los historiadores del reino de Valencia, sino para los de la propia Europa medieval, pues permitiría comprender con exactitud y solvencia documental cambios en las pautas de consumo doméstico de la Baja Edad Media. Además, el interés creciente por el consumo, los niveles de vida y los inventarios cobra fuerza en el panorama historiográfico en el mejor momento, en la era del ordenador y de las bases de datos, que permiten explorar la información de los inventarios con una agilidad analítica sin precedentes.

Conocer la naturaleza de la fuente, qué bienes recogían y por qué lo hacían es pues fundamental, pues ignorar esto puede llevar a juicios precipitados sobre la riqueza o pobreza de familias concretas. El fin del inventario no era recoger interiores domésticos, sino los bienes de individuos que acababan de fallecer y que pasaban a ser propiedad de otra persona. Este hecho pauta tanto lo que aparece como lo que no aparece en el documento,

\footnotetext{
${ }^{68}$ Los inventarios reportan ejemplos de viudas, mozos y jornaleros, como Alonso de Toledo, que consta en la mencionada tabla 4
} 
haciendo obligado para el historiador del consumo centrar la atención tanto en los objetos como en el dueño de los bienes. El lugar de éste dentro de la familia o el régimen por el que se regía su matrimonio condicionaba lo que le pertenecía y qué aparecía en el elenco notarial.Éstas y otras circunstancias legales han de comprenderse para identificar qué inventarios son por necesidad más parciales, como era el caso referido de mujeres y cohabitadores. Todo esto presenta al inventario como una fuente mucho más selectiva de lo que tradicionalmente se ha considerado, en la que jugaban un papel central los familiares, aquellos que identificaban ante el notario los bienes que eran del difunto y que se repartirían después. Es esta faceta la que hace comprender verdaderamente la naturaleza del inventario, explica su minuciosidad y también el hecho de que fueran capaces de reconocer e incluir los bienes del difunto por encima de su dispersión, a pesar de encontrarse en otras casas, localidades o incluso países.

Todo esto ocurría además en una sociedad donde el inventario post mortem era solicitado tanto por las élites como por las clases populares, tanto en el campo como en la ciudad, desde que se tiene constancia de la propia existencia del notariado a finales del siglo XIII. Cualquier familia del reino podía acceder $-\mathrm{y}$ accedía - a la redacción de inventarios, como muestra la existencia de unos precios perfectamente asumibles que, desde finales del siglo XIV, se hallaban regulados a la baja por la ley foral. Esto no sólo refleja la importancia que tenían en el ámbito privado, ante vicisitudes familiares concretas, sino también para el propio sistema en algo tan básico para la reproducción social y económica del reino como era la herencia. Más aún en un país joven, de inmigración constante y enormes oportunidades de promoción social, en el que había que asegurar que la riqueza cosechada en él podría pasar de una vida a otra en el mismo territorio de manera jurídicamente segura.

Los inventarios valencianos reúnen, en definitiva, las condiciones necesarias para emplear las metodologías de análisis seriado que ya se han emprendido en otros países para épocas posteriores. Yéstas son las que han permitido no sólo saber qué bienes se consumían, sino sobre todo conocer con precisión de décadas cambios en las pautas de consumo entre grupos sociales y dentro de ellos, explorando procesos de aumento o reducción de la desigualdad social. Éstas son las cuestiones que, conociendo las particularidades del inventario y con los métodos propios de la historia económica y social, pueden relacionar de manera directa los cambios en el consumo doméstico con transformaciones en el nivel de vida de la sociedad de la Baja Edad Media. 


\section{BIBLIOGRAFÍA CITADA}

Almenar Fernández, Luis (2014), Tableware in the late medieval Valencian rural world. A consumer revolution?, Cambridge, University of Cambridge (trabajo de fin de máster no publicado).

Barceló Crespí, Maria (1994), Elements materials de la vida quotidiana a la Mallorca baixmedieval: part forana, Palma, Institut d'Estudis Baleàrics.

Aparici Martí, Joaquín; Navarro Espinach, Germán (1996-1997), El libro memorial de la tutela del tejedor Joan Fretero: Segorbe 1432-1440, "Estudis castellonencs" 7, pp. 231-264.

Batlle Gallart, Carmen (1988), La casa i els béns de Bernat Durfort, ciutadà de Barcelona, a la fi del segle XIII, "Acta historica et archaeologica mediaevalia" 9, pp. 9-51.

Baulant, Micheline; Schuurman, Anton; Servais, Paul (1988), Inventaires après décès et ventes de meubles. Apports à une histoire de la vie économique et quotidienne, Lovaina la Nueva, Academia.

Benito i Monclús, Pere (2008), Casa rural y niveles de vida en el entorno de Barcelona a fines de la Edad Media, ponencia no publicada del coloquio Pautes de consum i nivells de vida al món rural medieval, http://www.uv.es/consum/benito.pdf [consulta: 18/05/2015].

Blondé, Bruno; Stabel, Peter; Boone, Marc (2006), Buyers and sellers: retail circuits and practices in medieval and early modern Europe, Turnhout, Brepols.

Bolòs Masclans, Jordi; Sànchez-Boira, Imma (2014), Inventaris $i$ encants conservats a l'Arxiu Capitular de Lleida (segles XIV-XVI), 3 vols., Lérida, Fundació Noguera.

Braudel, Fernand (1984), Civilización material, economía y capitalismo: siglos XV-XVIII, Madrid, Alianza.

Brewer, John; Porter, Roy (eds.) (1993), Consumption and the World of Goods, Londres, Routledge.

Briggs, Chris (2008), Manorial Court Roll Inventories as Evidence of English Peasant Consumption and Living Standards, c.1270-c.1420, ponencia no publicada del coloquio Pautes de consum i nivells de vida al món rural medieval, http://www.uv.es/consum/briggs.pdf [consulta: 18/05/2015].

Britnell, Richard Hugh (1996), The commercialization of English society, 1000-1500, Nueva York, Manchester University Press.

Colón, Germà; Garcia, Arcadi (1970-2007), Furs de València, 11 vols., Barcelona, Barcino. 
El digesto de Justiniano. Tomo II: Libros 20-36, version castellana por Álvaro D'Ors, F. Hernandez-Tejero, P. Fuenteseca, M. Garcia-Garrido, J. Burillo, Aranzadi, Pamplona, 1972

Dyer, Christopher (1998), Standards of living in the later middle ages: social change in England, 1200-1500, Cambridge, Cambridge University Press.

Dyer, Christopher (2005), An age of transition? Economy and society in England in the later Middle Ages, Oxford, Clarendon Press.

Ferragud Domingo, Carmel (2003), El naixement d'una vila rural valenciana: Cocentaina, 1245-1304, Valencia, Publicacions de la Universitat de València.

Ferrand, Guilhem (en prensa), Les inventaires après décès de la ville de Dijon à la fin du Moyen Âge (1390-1459), vol 1: 1390-1412, [próximamente en: Dijon, EUD]

Ferrer, Eloi (1926), Un inventari del segle XV, "Boletín de la Sociedad Castellonense de Cultura" 7/5, pp. 241-253.

Furió i Diego, Antoni (1982), Camperols del País Valencià. Sueca, una comunitat rural a la tardor de l'Edat Mitjana, Valencia, Institució Alfons el Magnànim.

Furió i Diego, Antoni (1998), Reproducción familiar y reproducción social: familia, herencia y mercado de la tierra en el Pais Valenciano en la Baja Edad Media, en García González, Francisco (ed.), Tierra y familia en la España meridional, siglos XIII-XIX, Murcia, Servicio de Publicaciones de la Universidad, pp. 25-43.

Furió i Diego, Antoni (2010), Producción agraria, comercialización y mercados rurales en la Corona de Aragón, en Sesma Muñoz, José Ángel (ed.), La corona de Aragón en el centro de su historia, 12081458. Aspectos económicos y sociales, Zaragoza, Gobierno de Aragón, pp. 363-425.

Gallent Marco, Mercedes (2010-2011), En el interior de los hospitales. Personas, espacios y enseres, "Saitabi" 60-61, pp. 81-104.

García Marsilla, Juan Vicente (1993), La jerarquía de la mesa. Los sistemas alimentarios en la Valencia bajomedieval, Valencia, Diputación de Valencia.

García Marsilla, Juan Vicente (2001), Imatges a la llar. Cultura material $i$ cultura visual a la València dels segles XIV i XV, "Recerques" 43, pp. 163-194.

García Marsilla, Juan Vicente (2008), La vida de las cosas. El mercado de objetos de segunda mano en la Valencia bajomedieval, ponencia no publicada del coloquio Pautes de consum i nivells de vida al món rural medieval, http://www.uv.es/consum/marsilla.pdf [consulta:18/05/2015]. 
García Marsilla, Juan Vicente (2011), Bellesa compartida. Confraries, oficis $i$ parròquies com a clients artístics a la València medieval, "Afers" 26, pp. 601-634.

Garcia-Oliver Garcia, Ferran (2003), La vall de les sis mesquites. El treball $i$ la vida a la Valldigna medieval, Valencia, Publicacions de la Universitat de València.

Garcia-Oliver Garcia, Ferran (2006), Pautes de consum i nivells de vida de la pagesia catalana: la casa i l'interior domèstic, en Bolòs Masclans, Jordi; Jarne, Antonieta; Vicedo, Enric (eds.), Condicions de vida al món rural: cinquè congrés sobre sistemes agraris, organització social i poder local, Lérida, Institut d'Estudis Ilerdencs, pp. 47-66.

Guinot, Rodríguez, Enric (2007), Morvedre. Història d'una vila valenciana medieval, "Braçal" 35-36, pp. 95-134.

Guinot Rodríguez, Enric (2014), Colonizaciôn feudal y génesis de las villasmercado al sur de la Corona de Aragon: la region de Morella y el Maestrazgo de Castellón en la coyuntura de 1300, en Bourin, Monique; Menant, François; To Figueras, Lluís (eds.), Dynamiques du monde rural dans la conjoncture de 1300: échanges, prélèvements et consommation en Méditerranée occidentale, Roma, Collection de l'École Française de Rome, pp. 339-363.

Guinot Rodríguez, Enric; Furió i Diego, Antoni (1980), Un exemple d'economia domèstica de principis del XVè. L'administració d'una tutela. Sueca 1412-27, "Quaderns de cultura de Sueca" 1, pp.11-46.

Hamilton, Earl J. (1936), Money, prices and wages in Valencia, Aragon and Navarre, 1351-1500, Cambridge (MA), Harvard University Press.

Isnard, Emile; d'Agnel, Arnaud (1914), Inventaires des mobiliers provençaux du XIIIe siècle tirés des archives de Marseille, "Bulletin archéologique du Comité des Travaux Historiques et Scientifiques" 3, pp. 97-107.

Julià, Eduardo (1921), Almoneda e inventarios valencianos, "Boletín de la Sociedad Castellonense de Cultura" 2, pp. 12-19; 38-39; 89-91; 264267; 332-337.

Kowaleski, Maryanne (2006), A consumer economy, en Horrox, Rosemary; Ormrod, William Mark (eds.), A social history of England, 12001500, Cambridge, Cambridge University Press, pp. 238-259.

Krueger, Paul (1877), Códex Iustinianus, Berlín, Weidmann.

Lencina Pérez, Xavier (1998), Espais i objectes quotidians. Els inventaris post mortem catalans en el context Europeu, "Pedralbes. Revista d'història moderna" 18/1, pp. 303-310.

López Ojeda, Esther (coord.) (2011), Comer, beber, vivir: consumo y niveles de vida en la Edad Media hispánica. XXI Semana de Estudios Medievales, Logroño, Instituto de Estudios Riojanos. 
Marzal Rodríguez, Pascual (1998), El derecho de sucesiones en la Valencia foral y su tránsito a la Nueva Planta, Valencia, Publicacions de la Universitat de València.

Mazzi, Maria Serena (1980), Gli inventari dei beni. Storia di oggetti e storia di uomini, "Società e storia" 7, pp. 203-214.

Mazzi, Maria Serena; Raveggi, Sergio (1983), Gli uomini e le cose nelle campagne fiorentine del Quattrocento, Florencia, Olschki.

McKendrick, Neil; Brewer, John; Plumb, J. H. (1982); The birth of a consumer society. The commercialization of eighteenth-century England, Londres, Hutchinson.

Moreno Claverías, Belén (2007), Consum i condicions de vida a la Catalunya moderna: El Penedès, 1670-1790, Villafranca del Panadés, Edicions i propostes culturals l'Andana.

Navarro Espinach, Germán (2005), La cultura material de los artesanos castellonenses en el siglo XV, "Boletín de la Sociedad Castellonense de Cultura" 81, pp. 405-422.

Overton, Mark; Whittle, Jane; Dean, Darron, Hann, Andrew (2004); Production and Consumption in English Households, 1600-1750, Oxford - Nueva York, Routledge.

Pardailhe-Galabrun, Annick (1989), L'inventaire après décès: une source incontournable pour l'appréhension de l'intime à l'époque moderne, en Laffont, Jean-Luc; Oge, Frédéric; Souriac, René (eds.), Histoire sociale et actes notariés. Problèmes de méthodologie, Toulouse, PUM - Presses de l'IEP, pp. 41-66.

Piponnier, Françoise (1980), Inventaires bourguignons (XIV $V^{E} X V^{E}$ siècles), en Van der Woude, Ad; Schuurman, Anton (eds.), Probate inventories. A new source for the historical study of wealth, material culture and agricultural development, Utrecht, HES, pp. 127-139.

Piponnier, Françoise (1987), La céramique dans son contexte quotidien d'après les inventaires bourguignons (XIV ${ }^{k}-X V^{E}$ siècles), en Chapelot, Jean; Galinié, Henri; Pilet-Lemière, Jacqueline (eds.), La céramique $\left(V^{e}-X I X^{e} s.\right)$. Fabrication, commercialisation, utilisation. Actes du premier congrès international d'archéologie médiévale, Caen, Société d'Archéologie Médiévale, pp. 235-244.

Ramos Palencia, Fernando Carlos (2011), Notas metodológicas sobre la utilización de los inventarios post-mortem: clasificación de bienes de consumo, bases de datos e impacto de créditos y deudas, 17501850 , en Muñoz Navarro, Daniel (ed.), Comprar, vender y consumir. Nuevas aportaciones a la historia del consumo en la España moderna, Valencia, Publicacions de la Universitat de València, pp. 21-52. 
Roche, Daniel (2000), A history of Everyday Things. The Birth of Consumption in France, 1600-1800, Cambridge, Cambridge University Press.

Salrach Marés, Josep Maria (coord.); Giralt i Raventós, Emili (dir.) (2004), Història agrària dels Països Catalans, 2. Edat Mitjana, Barcelona, Edicions Universitat de Barcelona.

Schuurman, Anton (1980), Probate Inventories: Research Issues, Problems and Results, en Van der Woude, Ad; Schuurman, Anton (eds.), Probate Inventories. A New Source for the Historical Study of Wealth, Material Culture and Agricultural Development, Utrecht, HES, pp. 19-31.

Sesma Muñoz; José Ángel; Laliena Corbera, Carlos (coords.) (2009), Crecimiento económico y formación de los mercados en Aragón en la Edad Media (1200-1350), Zaragoza, Universidad de Zaragoza.

Shammas, Carole (1990), The pre-industrial consumer in England and America, Oxford, Clarendon Press.

Sobrado Correa, Hortensio (2003), Los inventarios post-mortem como fuente privilegiada para el estudio de la historia de la cultura material en la Edad Moderna, "Hispania" 63/215, pp. 825-861.

Taraçona, Pere Hieroni (1580), Institucions dels furs y privilegis del regne de Valencia eo summari e reportori de aquells, Valencia, en la estampa de Pedro de Guete.

Torras, Jaume; Yun, Bartolomé (eds.) (1999), Consumo, condiciones de vida y comercialización. Cataluña y Castilla, siglos XVII-XIX, Ávila, Junta de Castilla y León.

Van der Woude, Ad; Schuurman, Anton (eds.) (1980), Probate inventories. A new source for the historical study of wealth, material culture and agricultural development, Utrecht, HES.

Vercher Lletí, Salvador (1992), Casa, família i comunitat veïnal a l'Horta de València. Catarroja durant el regnat de Ferran el Catòlic (14791516), Catarroja, Ajuntament de Catarroja.

Vercher Lletí, Salvador (2005), L'habitatge: la casa i l'interior domèstic. Guia bibliográfica, Corbera, Ajuntament de Corbera, Assemblea d'Història de la Ribera.

Viciano, Pau (1989), Catarroja. Una senyoria de l'Horta de València a l'època tardomedieval, Catarroja, Ajuntament de Catarroja.

Vries, Jan de (1993), Between Purchasing Power and the World of Goods: Understanding he Household Economy in Early Modern Europe, en Brewer, John; Porter, Roy (eds.), Consumption and the world of goods, Londres, Routledge, pp. 85-132.

Vries, Jan de (2008), The Industrious Revolution. Consumer Behavior and the Household Economy, 1650 to the Present, Cambridge, Cambridge University Press. 
Weatherill, Lorna (1996), Consumer behaviour and material culture in Britain, 1600-1760, Londres - Nueva York, Routledge.

Fecha de recepción del artículo: junio 2015

Fecha de aceptación y versión final: abril 2016 